
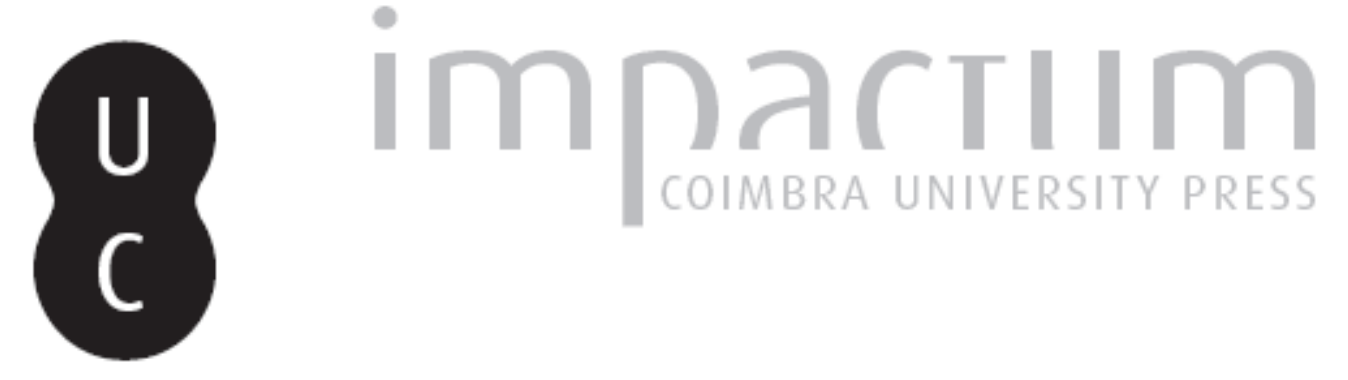

Teodorico de Freiberg: tratado sobre a origem das coisas categoriais

Autor(es): $\quad$ Augusto, Luís M., trad.

Publicado por: Faculdade de Letras da Universidade de Coimbra, Instituto de Estudos

URL

persistente:

URI:http://hdl.handle.net/10316.2/29584

DOI:

DOI:http://dx.doi.org/10.14195/0872-0851_40_9

Accessed : $\quad$ 26-Apr-2023 13:10:09

A navegação consulta e descarregamento dos títulos inseridos nas Bibliotecas Digitais UC Digitalis, UC Pombalina e UC Impactum, pressupõem a aceitação plena e sem reservas dos Termos e Condições de Uso destas Bibliotecas Digitais, disponíveis em https://digitalis.uc.pt/pt-pt/termos.

Conforme exposto nos referidos Termos e Condições de Uso, o descarregamento de títulos de acesso restrito requer uma licença válida de autorização devendo o utilizador aceder ao(s) documento(s) a partir de um endereço de IP da instituição detentora da supramencionada licença.

Ao utilizador é apenas permitido o descarregamento para uso pessoal, pelo que o emprego do(s) título(s) descarregado(s) para outro fim, designadamente comercial, carece de autorização do respetivo autor ou editor da obra.

Na medida em que todas as obras da UC Digitalis se encontram protegidas pelo Código do Direito de Autor e Direitos Conexos e demais legislação aplicável, toda a cópia, parcial ou total, deste documento, nos casos em que é legalmente admitida, deverá conter ou fazer-se acompanhar por este aviso.

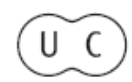




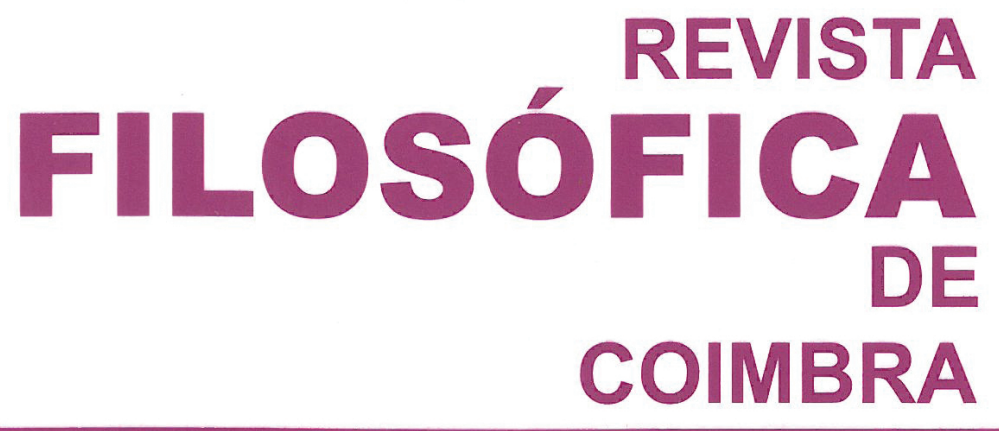

vol. 20 - número 40 - outubro 2011

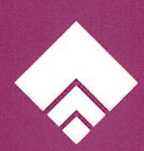




\title{
TEODORICO DE FREIBERG TRATADO SOBRE A ORIGEM DAS COISAS CATEGORIAIS
}

\author{
LUÍS M. AUGUSTO*
}

\section{Introdução ${ }^{1}$}

\section{O Tema: As Categorias}

Uma das temáticas fundamentais ditas filosóficas é constituída pelas categorias. Praticamente todos aqueles que na tradição ocidental são comummente vistos como "grandes filósofos" se debruçaram seriamente sobre esta questão, com textos fundamentais a marcar a história da filosofia ocidental e os currículos universitários contemporâneos: mencionamos, entre outros, Categorias de Aristóteles, Crítica da Razão Pura de Kant, e Investigações Lógicas de Husserl - sem esquecer a centralidade que Hegel lhes atribuiu na elaboração do seu sistema, nem tão-pouco a importância de Nietzsche, feroz crítico de categorias em geral e das categorias kantianas em particular, e ainda, no repensar da questão numa perspectiva existencialista, de Kierkegaard ou Sartre.

Não uma, mas várias problemáticas se formaram em torno das categorias. A problemática metafísica central radica no facto de as teorias sobre as categorias

\footnotetext{
* Instituto de Filosofia, Universidade do Porto.

${ }^{1}$ Publica-se aqui a tradução do texto em latim do filósofo alemão Teodorico de Freiberg (1250?-1310?) intitulado Tratado sobre a Origem das Coisas Categoriais. A publicação, acompanhada por uma introdução que compreende análises de cada um dos capítulos, far-se-á em três partes, reflectindo de certo modo a estrutura do texto. Trata-se, ao que sabemos, da primeira publicação da tradução integral deste texto para uma língua moderna. Esta tradução fez-se a partir do texto editado por L. Sturlese em DIETRICH VON FreIBerg, Opera Omnia III: Schriften zur Naturphilosophie und Metaphysik, Hamburg, Felix Meiner, 1983, pp. 137-201.Temos a agradecer a Burkhard Mojsisch a leitura atenta que fez de uma primeira tradução integral deste texto, também da nossa autoria, para inglês. Agradecemos ainda a Kurt Flasch, quem primeiro nos desafiou a encetar a tradução de um texto tido, talvez não sem fundamento, por extremamente difícil.
} 
almejarem o inventário exaustivo dos objectos (coisas; entes) que compõem o mundo, na medida em que são pensadas como os diferentes modos ou formas que o ser pode tomar; neste sentido, as categorias são os tipos ou as classes mais gerais ou comuns dos entes. A questão parece relevante, pois se possuirmos um tal inventário então teremos em mãos a resposta à questão "o que há no mundo?", uma questão na base de todas as ontologias regionais, ou seja, das ciências, tomadas individualmente, mas também de disciplinas como a ética e a estética. Contudo, não há acordo em relação a um tal inventário, com as diversas propostas a diferir entre si por vezes de modo conflituoso. Por outro lado, a resposta à questão "o que são as categorias?" permitir-nos-ia compreender o modo como conhecemos o mundo, pois que, para além de se pensar que elas são as formas ou modos de ser das coisas, há quem pense que elas são, também ou pelo contrário, os modos de pensar e/ou conhecê-las: neste sentido, fala-se de categorias do pensamento ou da razão, de categorias conceptuais, ou ainda linguísticas. Esta direç̧ão, cedo tomada por alguns pensadores (cf. abaixo), abriu mais recentemente as portas à psicologia científica, sendo a questão das categorias um dos problemas contemporâneos centrais da psicologia cognitiva e das ciências cognitivas. Se à primeira vista este alargar da problemática das categorias a outras disciplinas parece prometedor em termos de proliferação de teorias, o facto é que, também aqui, se instalaram a suspeita e a desunião entre as diversas abordagens. Face a estes conflitos, parece que a questão é simplesmente intratável de um ponto de vista filosófico, sendo relegada para terrenos menos frequentados da filosofia contemporânea.

Esta intratabilidade é, porém, radical, com as categorias a fomentarem agitadas discussões desde que Aristóteles se decidiu a reflectir sobre elas até ao momento em que o século XIII as retoma a fundo e Teodorico de Freiberg escreve um tratado exclusivamente dedicado à questão sob uma perspectiva em grande medida nova. Passemos ao essencial deste percurso que vai de Aristóteles a Teodorico de Freiberg.

\section{A lista aristotélica}

Ao que parece, segundo o seu criador, Aristóteles, a lista das dez categorias é a enumeração exaustiva dos géneros mais gerais do ente, ou seja, dos modos de ser de um ente. Por outras palavras, e num sentido mais lógico, a categoria é aquilo que se predica das coisas particulares, dos entes ( $\tau \hat{\omega} \nu$ ö $\tau \tau \omega)$, explicando-se assim a tradução de $\kappa \alpha \tau \eta \gamma o p i \alpha$ pelo termo latino praedicamentum (cf. verbo

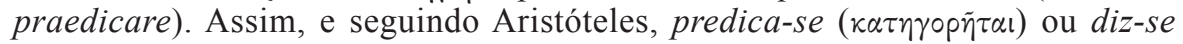
$(\lambda \varepsilon \dot{\gamma} \varepsilon \tau \alpha \iota)$ de uma coisa ou de um ente que é uma coisa determinada, ou seja, é uma substância (ex.: homem, cavalo), que tem uma determinada quantidade (por exemplo, a sua altura ou o comprimento) e uma certa qualidade (uma cor, por exemplo), que tem uma certa relação com outra coisa (é o dobro de $x$ ou metade de $y$, etc.), que se encontra num determinado lugar (ex.: na praça pública), num determinado momento (ontem, etc.), numa certa posição (deitado, sentado, etc.), num estado específico (ex.: calçado), e diz-se ainda dela que age ou pratica uma acção (ex.: corta) ou que, numa paixão, é objecto de uma acção (ex.: é cortado). 
Eis a tabela destas categorias aristotélicas no seu vocabulário grego original e na tradução latina que se tornou mais ou menos estabelecida:

\section{Quadro 1}

\begin{tabular}{|c|c|c|}
\hline Categoria & Nome Grego & Nome Latino \\
\hline 1. Substância & 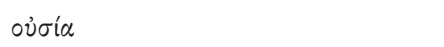 & Substantia \\
\hline 2. Quantidade & $\pi \circ \sigma \dot{v} \nu$ (= numa certa quantidade) & Quantitas \\
\hline 3. Qualidade & $\pi \circ 0^{\nu}(=$ de uma certa qualidade) & Qualitas \\
\hline 4. Relação & $\pi p o ́ s \tau l$ (= relativamente a algo) & Relatio; Ad aliquid \\
\hline 5. Lugar & $\pi \circ \dot{ } \quad(=$ num certo lugar $)$ & Ubi \\
\hline 6. Tempo & $\pi \circ \tau \dot{\varepsilon}(=$ num dado momento) & Quando \\
\hline 7. Posição & $\varepsilon \hat{\imath} 0 \theta \alpha \mathrm{l}$ (= estar posicionado) & Situs \\
\hline 8. Estado (ou posse) & $\varepsilon^{\prime} \chi \varepsilon เ \nu$ (= ter $)$ & Habitus \\
\hline 9. Acção & $\pi \circ เ \varepsilon \iota \nu$ (= fazer $)$ & Actio \\
\hline 10. Paixão & $\pi \dot{\alpha} \sigma \chi \varepsilon เ \nu$ (= sofrer) & Passio \\
\hline
\end{tabular}

A Lista das Categorias Aristotélicas

O primeiro problema que esta "lista" apresenta é o dos estatutos lógico e ontológico das categorias: é óbvio que há uma diferença entre a substância, que não se encontra em nada (aspecto ontológico) nem se predica de nada (aspecto lógico) (cf. Cat. V, 2a12-13), e as outras categorias, as quais por sua vez se predicam todas da substância ou se encontram nela enquanto sujeito ou substrato (cf. Cat. V, 2a34-5). Posto noutros termos - desenvolvidos por Aristóteles sobretudo na Metafísica -, a substância existe por si e em si mesma, não necessitando de mais nada para existir, enquanto as restantes nove categorias necessitam dela, não podendo, ao que parece, ser concebidas por si e em si mesmas. Assim, esta "lista" parece comportar não dez géneros do ente, mas apenas dois, a substân-

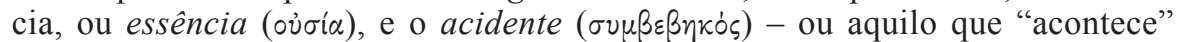

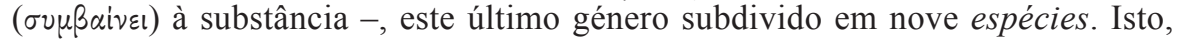
por sua vez, implica dois outros problemas intimamente ligados entre si: qual o modo de existir das categorias - material ou intelectual? -, uma questão que pertence tanto à física como à metafísica, e que mais cedo ou mais tarde obriga a uma reflexão epistemológica sobre o modo de se conhecer as categorias, nomeadamente a substância devido à sua metafísica aparentemente especial.

Estes problemas eram já patentes para Plotino (cf. Enéada VI, I. 1-3), a quem a concepção de categorias, em geral, e a sua pluralidade e número finito, em particular, repugnavam. Porfírio - seu discípulo, mas aparentemente discordante no que respeita à crítica que aquele lança sobre Aristóteles - vai introduzir uma nova 
problemática e marcar o rumo da reflexão sobre as categorias de modo definitivo. Retomando quase na totalidade uma listagem que Aristóteles faz em Tópicos (I, 5) dos predicáveis, as coisas que podem ser atribuídas a um sujeito, e ignorando aqui a lista das dez categorias, na sua introdução a Categorias, ${ }^{2}$ Isagoge, Porfírio estabelece em número de cinco aqueles que serão conhecidos como os universais ao longo da Idade Média, a saber, o género (genus), a espécie (species), a diferença (differentia), o próprio (proprium) e o acidente (accidens). Neste texto que, traduzido por Boécio para latim, despoleta o famoso problema dos universais no pensamento latino, Porfírio vê as categorias apenas como os predicáveis, na medida em que o que têm em comum é o facto de se predicarem de muitos (Isagoge [a Boethio translata], VI, 1; ed. de Libera \& Segonds: Commune quidem omnibus est de pluribus praedicari). Este aspecto lógico - ao qual, aliás, parece ser sua intenção reduzir a problemática (cf. ibid., 1) - era já manifesto em Categorias, mas o facto é que Porfírio abre a porta à problemática linguístico-gramatical que virá a marcar a história das categorias até aos nossos dias: desconhecia-se (e desconhece-se ainda) o título original do texto de Porfírio, mas nos manuscritos mais recentes o título era dado como ai $\pi \dot{\varepsilon} v \tau \varepsilon \phi \omega \nu \alpha i$, as quinque voces, ou os cinco vocábulos ou palavras; se é certo que falamos aqui de manuscritos dos séculos XIV e XV, o facto é que muito provavelmente um tal título germinasse já muito antes, e, a ser assim, as "categorias", originalmente objecto da metafísica, da lógica e da física, passarão desde cedo a ser reclamadas também pela gramática.

Tal parece de facto ter sido o caso: Simplício reconduziu as categorias à lista das dez consideradas por Aristóteles em Categorias, mas fá-lo dentro de uma perspectiva "contaminada" pela interpretação "linguística" que Porfírio lhes emprestara e que fora já de certo modo fixada por Alexandre de Afrodísia: para Simplício, e seguindo a posição de Alexandre, as categorias são mais propriamente partes do discurso (cf. In Praedicamenta [trad. G. de Moerbeke], 13; ed. Pattin).

Dão-se assim duas coisas interessantes a nível da problemática das categorias após a difusão da tradução de Boécio da Isagoge: a discussão passará a incidir mais propriamente sobre os cinco predicáveis de Porfírio e apenas mais indirectamente sobre as categorias propriamente ditas de Aristóteles, constituindo essa discussão a dita querela dos universais, e, por outro lado, as bastante menos discutidas dez categorias originais são frequentemente tomadas como partes do discurso ou simplesmente modos de falar, uma interpretação já conhecida por Teodorico e que ele aliás atribui ao próprio Aristóteles (cf. De origine, 3,12 ).

\section{Metafísica, Física, Lógica ou Gramática?}

A questão central do problema dos universais resume-se a saber se estes são coisas reais, res, existindo de modo extra-mental nas coisas, ou meros nomes,

\footnotetext{
${ }^{2}$ Note-se que Porfírio redigiu dois comentários sobre as categorias propriamente ditas de Aristóteles, In Aristotelis Categorias per interrogationem et responsionem, também traduzido - muito incompleta e "livremente" - por Boécio, e In Aristotelis Categorias ad Gedalium, do qual, ao que se sabe, não sobreviveu nenhum manuscrito.
} 
nomina, existindo simplesmente enquanto entidades mentais. Isto define os lados principais em oposição, o dos realistas e o dos nominalistas, embora uma terceira posição mais ou menos intermédia entre estas duas, a dos conceptualistas, não seja de ignorar, tomando estes os universais como conceitos. Na medida em que se pode dizer que a "lista" aristotélica das dez categorias é a listagem dos géneros mais comuns do ente, a problemática dos universais "alastra-se" para as categorias propriamente ditas. Temos assim três posições que, a mostrarem-se correctas, definiriam a disciplina em que as categorias deveriam ser tratadas: na metafísica, na física, na lógica, ou até na gramática, nas seguintes combinações, que variariam decerto em termos de proporções de importância atribuída a cada disciplina de acordo com abordagens mais ou menos individuais e nas quais sublinhamos a componente principal. Grosso modo:

- metafísica \& física (nomeadamente para os realistas);

- metafísica \& lógica (para os nominalistas);

- lógica \& gramática 3 (para os conceptualistas).

A problemática em torno dos universais e das categorias, já de si complexa, agudiza-se no século XIII com a introdução, pela via da recepção da filosofia árabe, ${ }^{4}$ das noções de intenção primeira (prima intentio) e intenção segunda (secunda intentio), as primeiras parecendo ser os conceitos das coisas existentes (ex.: homem é o conceito ou imagem mental de um homem) e as segundas os conceitos dos conceitos (ex.: homem é uma espécie do género "animal", ou ainda, numa acepção mais gramatical, um substantivo). A diferença entre as duas é maior do que à primeira vista pode parecer: as intenções primeiras são conceitos de coisas reais, de entes naturais, pelo que começarão a ser confundidas com as próprias coisas; a um dado momento, torna-se difícil dizer se as chamadas res primae intentionis são ainda conceitos ou já as coisas reais. Isto por oposição às coisas de intenção segunda, res secundae intentionis, meros entes de razão, entia rationis, sem qualquer existência real. A discussão em torno do texto aristotélico assume assim, na introdução das intentiones primae et secundae, contornos mais claros: Categorias tratar-se-á de um tratado sobre as coisas de intenção segunda - à excepção da substância, a qual é uma coisa de intenção primeira.

$\mathrm{O}$ autor do Tratado sobre a Origem das Coisas Categoriais (De origine rerum praedicamentalium) promete deitar achas na fogueira: ao afirmar, contra a corrente, que os géneros das categorias são de facto entes de intenção primeira, pelo que ele as chama propriamente coisas categoriais, res praedicamentales, Teodorico de Freiberg vai propor que, antes e além de serem o objecto de estudo do metafísico, do lógico e até mesmo do físico ou do gramático, elas são o objecto da noética, da disciplina que estuda as faculdades do intelecto; e isto na medida em que este é anterior à própria natureza! Se as coisas categoriais são

\footnotetext{
${ }^{3}$ Note-se a distinção extremamente problemática entre lógica e gramática na Idade Média.

${ }^{4}$ Cf. Gyekye, K. (1971). The terms 'prima intentio' and 'secunda intentio' in Arabic Logic. Speculum, 46, pp. 32-8.
} 
de facto coisas reais, é ao intelecto que o devem, pelo que interessa, a par de um estudo mais tradicional lógico-metafísico ou gramatical, mesmo ainda puramente matemático ou até teológico, investigar o modo como estes entes reais têm a sua origem no intelecto, o modo como o intelecto é a sua causa ou princípio.

Esta proposta equivale a pedir que se ignore a influente divisão do Aquinate entre os entes no mundo, ou seja, fora do espírito humano (extra animam), e os entes no espírito (in anima) (ex.: Super Sent. I, d. 2, q. 1., a. 3, co.); para Teodorico, esta distinção torna-se opaca, pois tanto os entes naturais reais como as categorias estão em pé de igualdade do ponto de vista do seu estatuto ontológico vistos a partir da sua constituição anterior à sua existência dita real ou natural, ou seja, vistos a partir da sua origem: o intelecto humano. Isto, por seu lado, põe em causa o estatuto meramente intelectual que ele começa por atribuir aos entia rationis ou coisas de intenção segunda, de modo a distingui-las das coisas de intenção primeira. Estamos, é claro, na transição do séc. XIII para o séc. XIV, face a um idealismo epistemológico, contra o que ditam as histórias da filosofia das auctoritates que limitam as "grandes" epistemologias medievais ao realismo ${ }^{5}$.

\section{Uma "Revolução Copernicana"?}

Teodorico de Freiberg atribui às categorias o carácter ontológico de coisas de intenção primeira, ou entes reais, e fá-lo deslocando-as da natureza e colocando-as no intelecto humano em termos de causalidade. Teodorico vai tão longe quanto pode: ele fala de constituição; do objecto do conhecimento, decerto, mas também do objecto, tout court. Isto levou Kurt Flasch, em dois artigos ${ }^{6}$ que quase fizeram escola (a "Escola de Bochum"), a ver neste autor o inceptor da Idade Moderna, se não mesmo de uma Aufklärung. Mais precisamente, embora, segundo ele, não se possa ver Teodorico como o antecipador de Kant, não será talvez despropositado vê-lo como o feitor da Revolução Copernicana que este se auto-atribuiu e que define em grande medida aquilo que hoje vemos como o pensamento moderno. Sob a perspectiva da história das ideias, contudo, não se pode dizer que Teodorico de Freiberg efectuou uma, ou a, "Revolução Copernicana", e isto pela mesma razão que não se pode dizer que Kant a realizou. O filósofo de Königsberg acreditava honestamente ter revolucionado o panorama filosófico ao afirmar que as categorias não são dos objectos, mas do entendimento humano; a concepção daquela que é conhecida como a tábua das categorias seria a listagem dos modos que temos de percepcionar e conhecer (se não de pensar, mas aqui

${ }^{5}$ Cf., por exemplo, Gilson, É. (1989). L'esprit de la philosophie médiévale. Paris: Vrin, p. 234: «toutes les grandes épistémologies médiévales [ont] été ce que nous appellerions aujourd'hui des réalismes. »

${ }^{6}$ Flasch, K. (1972). Kennt die mittelalterliche Philosophie die konstitutive Funktion des menschlichen Denkens? - Eine Untersuchung zu Dietrich von Freiberg. Kant Studien, 63, pp. 182-206; Flasch, K. (1978). Zum Ursprung der neuzeitlichen Philosophie im späten Mittelalter. Philosophisches Jahrbuch, 85, pp. 1-18. 
os limites são outros...) os objectos, os quais, fora da acção do entendimento, seriam númenos, ou coisas em si.

Com efeito, antes dele, Teodorico de Freiberg traça os primeiros esquiços de uma listagem que é, em grande medida, das categorias do sujeito: trata-se, como ele nos diz, dos princípios formais de acordo com os quais o objecto é conhecido (intelligitur) pelo sujeito cognoscente. Teodorico lista estes "princípios formais" num tratado posterior ao De origine, o De intellectu et intelligibili (cf. III, 34). Aqui, ele diz-nos que o objecto do intelecto tem que, entre outras propriedades, ser um ente (ou seja, possuir entitas) e verdadeiro (verum), que ele tem ainda que ser necessário e eterno, por essência e universal. Ora, entidade, verdade, necessidade, permanência e inalterabilidade, essencialidade e universalidade são, segundo ele, os princípios do intelecto que permitem que o objecto seja não só conhecido, mas seja, pura e simplesmente. Ou seja, estamos face a princípios constitutivos das coisas. Aqui, o adjectivo formal refere-se à forma pela qual uma coisa é não só conhecida mas se distingue originalmente do nada ou do não-ente: esta forma encontra-se com efeito na coisa a conhecer, ou seja, ela é in re, mas aí ela não é princípio de conhecimento; decerto, ela será também ante rem, no verbo divino, mas também aqui ela não é princípio de conhecimento humano: se uma coisa deve ser conhecida, ou lida no seu interior (intelligere = intus legere), os princípios pelos quais ela o deve ser têm que se encontrar no intelecto, post rem, como ensinara Alberto Magno (cf. Super Porphyrium de V universalibus, II, cap. 3; ed. Noya).

Ao reintroduzir de forma explícita estes universais post rem na discussão em torno dos universais, ${ }^{7}$ e ao deslocar claramente o problema posto por Porfírio na Isagoge para o intelecto humano, o filósofo de Colónia havia já encetado por uma via que prometia, se fértil, levar a uma "epistemologia do sujeito" acontece que já o próprio Aristóteles o fizera, ao suspeitar que, sem um sujeito de conhecimento, as formas platónicas seriam inúteis do ponto de vista da cognição9 . Concluímos, pois, que, a falar-se de "Revolução Copernicana", em Kant, ou até mesmo em Teodorico de Freiberg, temos que o fazer de forma mitigada.

\section{O Texto}

O Tratado sobre a Origem das Coisas Categoriais, cuja redacção K. Flasch data de cerca de $1286,{ }^{10}$ apresenta-se como um texto altamente original a vários

7 Cf. de Libera, A. (1996). La querelle des universaux. Paris : Seuil. Ver, mais especificamente, pp. 253ss, para esta tripartição dos universais antes da sua retomada por Alberto Magno.

${ }^{8}$ Ver Augusto, L. M. (2009). Albertus Magnus and the emergence of late medieval intellectualism. Mediaevalia. Textos e Estudos. [no prelo]

${ }^{9}$ Cf. Augusto, L. M. (2006). A little idealism is idealism enough: A study on idealism in Aristotle's epistemology. Idealistic Studies, 36, pp. 61-73.

${ }^{10}$ Flasch, K. (2007). Dietrich von Freiberg. Philosophie, Theologie, Naturforschung um 1300. Frankfurt am Main: Vittorio Klostermann. Cf. pp. 31 ss. 
níveis, dos quais ressalta, para além da "revolução idealista" que faz das categorias entes de intenção primeira e do intelecto o constituinte da realidade, uma presença marcada de "novas autoridades". As principais autoridades são, diz-nos Teodorico, Aristóteles e os peripatéticos. Com efeito, a presença de Aristóteles é secundada, em termos de "citações", pela de Averróis, o primeiro como autor da Metafisica, sobretudo, e o segundo como o comentador desta. Seguem-se as auctoritates menos citadas mas de não menor significado: Avicena (como autor da Logica), Agostinho de Hipona (De trinitate; Confessiones; etc.), Boécio (vários textos), Anselmo (como autor do Monologion), o Liber de causis, e ainda o Liber sex principiorum, de autor anónimo.

Uma tal escolha de autoridades não poderia ser mais arrojada, pois não só estão ainda incandescentes as condenações de 1270 e 1277, que alvejavam sobretudo o pensamento dito peripatético, mas pairam ainda na paisagem filosófica os Erros dos Filósofos, atribuídos a Egídio Romano, entre os quais constavam a unidade da forma substancial, atribuído a Aristóteles - e também a Avicena -, e a unidade do intelecto, atribuído a Averróis, "erros" que Alberto Magno, se não apadrinhara, incautamente não rejeitara com o fervor necessário.

Ora, Teodorico parece ter-se decidido de forma resoluta a, não só abordar a temática das categorias a partir da perspectiva peripatética, mas ainda, e mais propriamente, a reformulá-la dentro de uma perspectiva noético-epistemológica. Contudo, havia que ainda argumentar contra as ideias feitas sobre as categorias, as quais se enquadravam na perfeição dentro desta paisagem algo ensombrada em que a filosofia se pratica nestes finais do séc. XIII. Teodorico resolve o problema de forma algo engenhosa em termos de estrutura do seu texto: os dois primeiros capítulos - em que desenvolve a questão da origem das coisas categoriais em geral e da substância em particular, bem como das determinações que se encontram na substância, os vulgarmente, mas nem sempre (ou mesmo nunca) correctamente, chamados acidentes - formam com o quinto e último, em que se trata de defender os "acidentes" como sendo coisas de intenção primeira, ou entes reais, uma unidade. Com efeito, a unidade é tal que o tratado se poderia circunscrever a estes três capítulos. Porém, a tese a defender é decerto ousada (para não dizer herética, na medida em que ignora ou mesmo rejeita aspectos ontológicos fundamentais à teologia escolástica), e há que a integrar nas discussões lógico-ontológicas em torno das categorias e dos (não-)entes, as quais não dispensavam questões como a relação entre a potência e o acto, a privação, a geração e a corrupção, e, acima de tudo, o já mencionado "erro" da unidade da forma substancial, a qual constituía, aliás, um pomo de discórdia com os Franciscanos. Há, pois, que abordar estas questões, e Teodorico, um "Dominicano de gema", fá-lo após discutir os modos de criar ou originar os entes (Capítulo 1) e os tipos de entes (distinguidos entre substância e "acidentes"; Capítulo 2), mas antes de (re)afirmar e elaborar de modo definitivo as teses "revolucionárias" do último capítulo; os Capítulos 3 e 4 aparecem, assim, neste tratado como "excrescências ontológicas" - se, é claro, tomarmos o ponto de vista exclusivista da noética.

Por outro lado, há que conceder que se Teodorico pretende rejeitar que as categorias, nomeadamente os ditos acidentes, mas também os predicáveis de Porfírio ou universais, sejam meros entes de razão, ou não-entes, então convém 
levar a cabo uma argumentação aturada, como era exigência da época, sobre a questão da distinção entre o ente e o não-ente. É precisamente isto que o autor do De origine faz nos capítulos 3 e 4 . Ao fazê-lo, pode bem ter compactado num só texto aquilo que Porfírio fizera em dois ou três, a Isagoge, a introdução às categorias aristotélicas mas que trata apenas dos predicáveis ou universais, e os comentários às mesmas (cf. acima); uma questão a explorar.

Uma outra questão importante - entre muitas - ainda por investigar é se a promessa que o tratado de Teodorico sobre as categorias transportava em si de deitar achas na fogueira se realizou de facto, ou se o texto caiu no mais profundo esquecimento. É certo que as referências a Teodorico, com relação a este ou aos restantes dos seus textos, são escassíssimas, mas muitas vezes as influências doutrinais escondem-se sob formas subtis que cabe à história das ideias desvelar. Por exemplo, e como se viu acima, há aspectos extremamente próximos entre os pensamentos de Teodorico e de Kant no que diz respeito a esta temática, mas tanto quanto sabemos o filósofo de Königsberg não teria tido conhecimento deste compatriota. Haverá uma linha escondida de transmissão entre ambos? A poder de facto falar-se de uma "Revolução Copernicana", não terá sido Teodorico o seu feitor? Por enquanto, vejamos qual o conteúdo do tratado de Teodorico sobre as coisas categoriais nas suas partes constituintes.

\section{Introdução Analítica às Diferentes Partes do Tratado}

\subsection{A Introdução}

Num curto prooemium, Teodorico informa o leitor do tema do tratado e da sua abordagem: trata-se de investigar o ente comum (ens commune), sem o qual o ente particular (ens particulare) não se pode conhecer, e trata-se de o fazer segundo os peripatéticos. Por outras palavras, o objectivo do tratado é o de investigar os entes que se predicam de todas as outras coisas, os ditos universais, e especificamente as categorias ou, como ele lhes chama, as coisas categoriais (res praedicamentales), estabelecidas por Aristóteles no número de dez em Categorias. Mas o objectivo principal de Teodorico não é o de investigar as coisas categoriais em geral: o seu interesse principal recai na origem destas, na sua causa originária, tarefa que ele se impõe levar a cabo em cinco capítulos bem delimitados:

Capítulo 1: Teodorico abordará a origem das coisas categoriais, em especial da substância.

Capítulo 2: Os acidentes, ou seja, "os entes que existem numa substância" e, de modo geral, os géneros que se distinguem da substância, constituem a temática central deste capítulo.

Capítulo 3: O tema será a pertença ou exclusão em relação a um género.

Capítulo 4: Teodorico debruçar-se-á sobre o que faz com que um ente em primeiro lugar e formalmente difere do nada ou do não-ente, ou seja, o que é que faz com que um ente o seja de facto. 
Capítulo 5: O objectivo é aqui mostrar que a causa das coisas categoriais é o intelecto, mas que tal não faz com que elas sejam coisas de intenção segunda ou meras coisas de razão; pelo contrário, elas são coisas de intenção primeira.

Teodorico termina esta introdução afirmando que a sua abordagem será puramente filosófica, nomeadamente peripatética na essência, comunicando indirectamente ao leitor que a abordagem teológica, inseparável da metafísica na escolástica medieval, é ausente neste tratado.

\subsection{Capítulo 1}

Passamos a segmentar este capítulo em unidades de conteúdo e a explicar o mesmo:

$(1,1-4)$ Teodorico informa o leitor de que há três modos de originar (ou criar, numa acepção não-teológica) um ente, sendo que dois deles são já bem conhecidos na tradição metafísica ocidental: um ente é originado ou "principiado" (principiatur) por causas ou princípios extrínsecos ao ente (as causas eficiente e final de Aristóteles), ou por causas ou princípios intrínsecos ao ente (a matéria e a forma nas coisas compostas, ou as causas material e formal de Aristóteles). No primeiro modo, algo - uma causa, segundo Averróis - constitui um ente no seu ser "a partir de fora" (extrinsecus), ou seja, algo é um princípio causal que se encontra fora da essência do ente; no segundo modo, algo - um elemento, segundo Averróis - constitui um ente "a partir de dentro" (intrinsecus) na medida em que faz parte da sua essência. Averróis considera a combinação deste dois modos, falando aqui de princípios. Mas esta combinação não é de facto o terceiro modo que Teodorico afirmara ainda existir.

$(1,5)$ Este é um modo ainda inominado, no qual "algo é o princípio de uma outra coisa de tal maneira que graças a esse mesmo princípio existindo fora da essência daquilo do qual é o princípio, graças a esse mesmo princípio subsiste contudo formalmente aquilo do qual é o princípio na medida em que toma desse mesmo princípio, a partir do seu próprio conceito, a noção da sua entidade ou quididade. Pelo que pertence à definição desse ente exprimindo aquilo que ele é enquanto ente". Ou seja, trata-se aqui de um princípio que é extrínseco ao ente mas graças ao qual ele subsiste formalmente porque é dele que ele recebe a sua entidade ou quididade, mais especificamente, do seu próprio conceito; assim sendo, esse princípio pertence à definição do ente, àquilo que formalmente exprime o que o ente é enquanto ente. Como veremos, este princípio causal é o intelecto. Note-se, desde já, o vocabulário lógico-metafísico: essentia, formaliter, subsistit, ratio (noção), entitas, quiditas, intellectus (aqui: conceito).

$(\mathbf{1}, \mathbf{6}-12)$ Teodorico vai agora explicar de que modo a noção de ente (ratio entis), "a primeira de todas as intenções e graças à qual uma coisa primeiro difere formalmente do nada" $(\mathbf{1}, \mathbf{7})$, varia de acordo com os três modos acima. Começa pelo segundo modo: quando os princípios são intrínsecos, uma coisa tem, formalmente, em si e de modo absoluto, a noção de ente, subsistindo formalmente graças a esse princípio que é a forma nas coisas compostas ou a essência sem mais nas coisas ditas simples (cf. 1, 7). Trata-se aqui da 
substância, o objecto do metafísico (cf. 1, 12). Dá-se o caso de facto que as substâncias podem "sustentar" entes que nelas inerem, mas se tomadas somente em termos dos seus princípios intrínsecos, não se fala então de acidentes, mas sim de propriedades (ex.: o uno e o múltiplo), que são com efeito essenciais a uma coisa (cf. 1, 9-11).

(1, 13-15) Passamos agora ao primeiro modo, no qual só os princípios extrínsecos são tomados em consideração: desde logo, diz-nos Teodorico, uma coisa perde a noção de ente que têm os entes que são considerados apenas com respeito aos seus princípios intrínsecos. Estamos agora face às coisas naturais (res naturae), criadas a partir de uma operação natural (a causa eficiente) em vista de um fim (a causa final) estabelecido pela natureza. Mas por "coisas naturais" Teodorico não entende somente as coisas que estão sujeitas ao movimento e ao repouso (uma perspectiva restrita de natureza), abarcando todas as coisas que são fruto de uma qualquer operação real (vs. operação intelectual), o que permite a consideração dos entes separados (entia separata) (as inteligências, intelligentiae) como também eles coisas naturais. Dividindo-se assim as substâncias em sensíveis e inteligíveis (os entes separados ou inteligíveis), verifica-se que estas últimas, a existirem de facto, serão pela sua essência originariamente aptas a subsistir com relação a um fim e a participar na perfeição do seu fim, sendo logo por essência o princípio da sua própria operação $(\mathrm{cf} . \mathbf{1 , 1 4})$, pelo que nelas não poderá haver nenhuma natureza extrínseca à sua essência, ou seja, não podem ter acidentes; as primeiras, porém, porque necessitam de uma transmutação alteradora e geralmente movente que lhes é extrínseca, necessitam de acidentes, os princípios activos ou passivos dos seus movimentos (cf. 1, 15).

$(\mathbf{1}, \mathbf{1 6 - 1 7})$ Teodorico vai agora enumerar os acidentes, ou os princípios desses movimentos naturais: são eles, por ordem de importância ontológica do ponto de vista da operação natural, a quantidade e a qualidade.

$(1,18)$ Todos os restantes acidentes considerados na tabela aristotélica das categorias (relação, lugar, tempo, posição, posse, acção e paixão) não são porém fruto de uma operação natural, visto que "a natureza não age senão em relação a um fim, o qual é uma certa natureza e o qual uma coisa alcança pela sua operação natural ou real".

$(1,19)$ Teodorico informa-nos de que há apenas dois tipos de princípios, a natureza ou o intelecto; ora, e como é óbvio, se estes acidentes não são constituídos por uma acto natural, sê-lo-ão pois pelo intelecto. Temos então sete géneros de entes que são constituídos pelo intelecto, mas - e eis o fulcro da problemática lançada por Teodorico - não são por isso meras coisas de intenção segunda (res secundae intentionis) ou meras coisas de razão, as quais mais não são que formas da razão pelas quais as coisas se tornam inteligíveis (ex.: categorias gramaticais); pelo contrário, estes sete acidentes são considerados por Teodorico como sendo coisas de intenção primeira (res primae intentionis), o que as põe em pé de igualdade ontológica com as coisas concretas de que o mundo é composto (animais, plantas, pedras, etc.). A conclusão que se tirará posteriormente é revolucionária: o intelecto cria coisas reais, objectos do mundo real.

$(\mathbf{1}, \mathbf{2 0})$ Mas antes disso importa explicar como é que estes entes constituídos pelo intelecto são coisas de intenção primeira, como as coisas naturais: o intelecto 
determina-os em relação a estas coisas como formas ou modos de entes naturais, razão pela qual tomam a sua entidade dos entes naturais, os quais fazem assim parte da sua definição; quer isto dizer que sendo algo de um ente real por uma operação da natureza, que é um ente de intenção primeira, participam do modo de ser destes entes, sendo também eles entes de intenção primeira, mas constituídos neste ser pelo intelecto ${ }^{11}$. Diferem porém dos entes naturais na medida em que o seu fim não é uma qualquer natureza, mas uma perfeição que adquirem pela acção do intelecto.

(1, 23-24) Razão pela qual não são substâncias, as quais "têm em si e de modo absoluto a noção de ente completo, tanto no que diz respeito à perfeição do seu acto formal como no respeitante à perfeição do fim" $(\mathbf{1}, \mathbf{2 4})$; o terceiro modo de principiar um ente $(\mathrm{cf} . \mathbf{1 , 5})$ é aquele que consiste em um ente ser formalmente algo de algo ou ser a partir de algo em termos da forma, o que só pode convir aos entes que existem numa substância como um modo ou determinação (ou disposição) desta, ou ainda como uma propriedade de uma substância ou de algo de outra natureza (cf. 1, 24).

$(\mathbf{1}, \mathbf{2 5 - 3 0 )}$ Teodorico explica que pelo facto de estes entes do terceiro modo serem ou acidentes de facto ou terem o modo de acidentes, tal não implica um estatuto de ens diminutum, ente inferior, pois que a sua essência consiste precisamente em ser algo de um ente que é uma substância; sendo um ente, ou seja, distinguindo-se formalmente do nada, um ente deste modo não pode simplesmente "acontecer", ser por acidente. Assim, a única diferença no estatuto ontológico (ou ôntico, mais precisamente) da substância e do ente deste tipo é que a substância é ente pela sua própria essência em termos de subsistência absoluta, enquanto os entes que existem na substância são entes por essência mas em relação à substância. Mas esta relação não é causal da parte da substância, nem esta é um sujeito em termos de inerência; trata-se da relação já mencionada, ou seja, na qual este ente é um modo ou uma determinação (ou disposição) de uma substância.

\subsection{Capítulo 2}

Teodorico vai agora debruçar-se sobre os entes do terceiro modo, os entes que existem numa substância, comummente - mas não correctamente - chamados acidentes. Os entes que existem numa substância são de quatro tipos; esta divisão é em grau e ordem, conforme o grau e a ordem no modo pelo qual eles tomam formalmente a sua entidade a partir de um outro ente. Em comum têm o facto que todos são entia entis, ou sejam, pertencem a um ente. Destaca-se ainda que são entes por essência, e não pela mera designação.

\section{Tipo I}

(2, 8-17): Algo pertence a um ente segundo a noção formal e definitiva do ente a que pertence, nomeadamente em termos da sua quididade. Não se

11 Ver nas notas de rodapé a argumentação detalhada de Teodorico. 
trata de acidentes, mas mais propriamente de propriedades, podendo ser de dois tipos:

\section{Propriedades}

Tipo I. 1. (cf. 2, 9) Existem numa coisa de modo essencial e absoluto, implicando nela uma privação na sua ausência. Ex.: o uno e o múltiplo.

Tomam a sua entidade do sujeito. Ex.: o par e o ímpar tomam a sua entidade do número.

Tipo I. 2. (cf. 2, 10) Existem numa coisa em termos da sua essência, mas em relação a outra coisa. Ex.: causa - causado; potência activa - potência passiva.

Tomam a sua entidade da noção formal do sujeito mas com relação a outra coisa.

Estes entes não são fruto de um acto natural! Têm o seu princípio no intelecto de modo como que produtivo (quasi effective), num modo como que subjectivo (quasi subiective) na substância ou essência de uma coisa, e de modo como que originário e informativo (quasi originaliter et informative) na noção de uma coisa (cf. 2, 14). Porque é que os entes deste tipo não são entes naturais? Teodorico responde: porque 1) não são o princípio de uma qualquer operação natural (cf. 2, 11), 2) não dizem respeito a uma transmutação real (cf. 2, 12), e 3 ) existem independentemente de toda a transmutação natural. Acima de tudo, visto que eles são produzidos a partir da noção formal do sujeito, é o intelecto que os produz, pois que a natureza não distingue entre a coisa-sujeito e a noção da coisa-sujeito, a qual noção é já ela também constituída pelo intelecto (cf. 2, 14-15). Resulta assim que os entes do tipo I são todos produzidos pelo intelecto.

Não se trata ainda das categorias, mas tão-somente de propriedades ou afecções próprias dos entes naturais. Possuem, de modo geral, uma "entidade diminuta", não tendo uma noção de ente completa, podendo porém possui-la e constituir um género de categoria se forem tomados a partir das determinações naturais de algum ente (ver Tipo III abaixo).

\section{Tipo II}

(2, 18-33): Um ente é algo de um ente de acordo com esse mesmo ente como sujeito. Teodorico começa por distinguir dois modos segundo os quais uma coisa pode ter a noção de sujeito: 
Noção de Sujeito

A. Uma coisa é sujeita - substá - a outra nela inerente formalmente, de modo que delas se forma um ente uno como a partir de um sujeito e de uma forma. Temos aqui a substância como substare.

B. Uma coisa sustenta, ao subsistir [em si mesma], uma qualquer natureza ou disposição a ela aderente. A substância como suporte de propriedades naturais: qualidades e quantidades reais, bem como transformações naturais (motus). Estes entes têm a sua causa na natureza.

Os entes de que se vai tratar pertencem ao modo $\mathbf{B}$, na medida em que são criados como disposições ou determinações naturais que, embora extrínsecas, determinam um ente ao aderir a ele (cf. 2, 20); pelo contrário, em A estamos perante meros acidentes (cf. 2, 20 e 2, 26). Estamos pois agora no domínio dos entes naturais, pois que eles são criados num sujeito em vista de um fim. Estes entes deste segundo tipo, as determinações ou disposições naturais, "importam" em relação às substâncias certas naturezas que são os princípios das suas operações naturais ou dos seus movimentos. São de dois tipos:

II.1. Qualidades reais: Quando se trata de princípios num modo essencial e originário. A natureza determina em relação a coisas determinadas segundo a sua existência específica a sua própria qualidade (cf. 2, 29; 2, 31).

II.2. Quantidade, movimento local: Trata-se de princípios de modo essencial, mas não de modo originário. A natureza determina em relação a coisas determinadas segundo a espécie determinados movimentos e quantidades (cf. 2, 30-1).

Para uma distinção clara entre este tipo de entes e os entes do Tipo I, ver nota de rodapé a $\mathbf{2}, \mathbf{3 2}$.

\section{Tipo III}

(2, 34-54): Um ente é algo de um ente segundo esse mesmo ente-sujeito e segundo outra coisa que existe nesse mesmo sujeito.

Teodorico começa por interpretar a teoria de Aristóteles sobre a relação elaborada no livro V, secção 15, da Metafísica; segundo ele, os relativos são de dois modos:

1. Sem que os termos sejam específicos de um mesmo género:

a) Causa e causado: ambos se relacionam um com o outro essencialmente

b) Medida e medido: o primeiro relaciona-se por si mesmo e o segundo acidentalmente 
2. Termos pertencentes a um mesmo género:

a) Activos e passivos (não por essência); igual e desigual: os termos são relativos por si e classificados no género da relação

b) O conhecimento e o cognoscivel; a sensação e o sensivel: um dos termos é relativo por si, o outro é-o por acidente

Quadro 2

\begin{tabular}{|c|c|c|c|}
\hline \multicolumn{4}{|c|}{ RELAÇÃO } \\
\hline \multicolumn{2}{|c|}{$\begin{array}{l}\text { Termos não necessariamente pertencen- } \\
\text { tes a um mesmo género }\end{array}$} & \multicolumn{2}{|c|}{ Termos pertencentes ao mesmo género } \\
\hline $\begin{array}{l}\text { Os dois termos são } \\
\text { relativos por si ou es- } \\
\text { sencialmente }\end{array}$ & $\begin{array}{l}\text { Um dos termos } \\
\text { é relativo por } \\
\text { si, o outro é-o } \\
\text { por acidente }\end{array}$ & $\begin{array}{l}\text { Os dois termos são } \\
\text { relativos por si ou } \\
\text { essencialmente }\end{array}$ & $\begin{array}{l}\text { Um dos termos é re- } \\
\text { lativo por si, o outro } \\
\text { é-o por acidente }\end{array}$ \\
\hline CAUSA E CAUSADO & $\begin{array}{l}M E D I D A \\
M E D I D O\end{array}$ & $\begin{array}{l}\text { ACTIVO E PASSIVO } \\
\text { (não por essência); } \\
\text { IGUAL E } \text { DESI- } \\
\text { GUAL }\end{array}$ & $\begin{array}{l}\text { O CONHECIMENTO } \\
\text { E O COGNOSCÍVEL; } \\
\text { A SENSAÇAOO E O } \\
\text { SENSÍVEL }\end{array}$ \\
\hline
\end{tabular}

A Relação para Aristóteles segundo Teodorico

Teodorico "relativiza" esta concepção aristotélica, mostrando que a relação é, pelo conceito que envolve, provavelmente a mais problemática das categorias. Com efeito, em termos da sua entidade, estes entes deste terceiro tipo podem ser de dois modos na medida em que são formas tornando-se intrinsecamente presentes: 1) se tomam a sua entidade de um outro segundo a noção formal deste, então são propriedades de uma coisa natural (pertencem ao tipo em $2,2)$; 2) se tomam a sua entidade a partir de uma outra coisa que se encontra numa substância, são entes classificáveis num género pelo facto que a coisa de acordo com cuja noção formal e definitiva são tomados é uma determinação natural de uma substância (o tipo em 2,3). Ou seja, Teodorico "reduz" a relação aos dois outros tipos de entes (a saber, Tipos I e II) que têm a sua origem de acordo com o terceiro modo de "constituição". São entes de intenção primeira pela analogia segundo a qual um ente de um ente tem o carácter completo de ente, embora os entes a partir dos quais tomam a sua entidade sejam "ônticamente mais remotos" ou "menos entes" na medida em que eles próprios já são entia entis, ou seja, acidentes ou determinações naturais de um ente real (pelo que se trata de facto de uma analogia dupla, segundo Teodorico; cf. 2, 48). Se quisermos reduzir estes entes às suas causas, eles são a partir de uma operação do intelecto: a natureza não produz nem realiza nada a partir da noção de uma coisa, tal como não distingue entre a coisa e a noção da coisa, mas esta é a obra própria do intelecto. Assim, se removermos destes entes o acto da razão, resta somente a realidade e a entidade do seu fundamento, pelo que não são considerados como propriamente entes; mas a questão que se põe é se 
é possível conceber uma "fundamentação" puramente natural, na ausência de uma "fundamentação" formal por parte do intelecto. A ser o caso, será muito provavelmente uma "fundamentação"secundária ou mesmo artificial - como ele nos diz, apenas pela designação, secundum solam denominationem $(\mathbf{2}, \mathbf{5 3})$.

Que Teodorico inicie esta "relativização" por uma brevíssima discussão de carácter teológico (cf. $\mathbf{2 , 4 0}$ ) pode mais não significar que um modo conveniente de "atacar" um dos seus oponentes de predilecção, Tomás de Aquino, para quem a relação que Deus tem com os entes criados (ou seja, Deus > ente criado) é meramente intelectual ou ideal, na medida em que Deus, embora "real", não faz parte da "realidade criada" (cf. Summa theol. I, q. 13. a. 7 co.). Mais especificamente, esta discordância é relativa ao carácter real ou meramente ideal das relações e dos termos relativos: para Teodorico, se o ente relativo por essência é real, o ente que com ele se relaciona de modo acidental é também ele real (cf. $\mathbf{2 , 4 1}$ ). Isto vai levar a uma discussão (cf. 2, 49-53) sobre a ontologia da relação fundamento-"acidente" acima referida.

\section{Tipo IV}

(2, 55-62): Um ente é algo de um ente segundo estes entes-sujeito e em termos de outra coisa que existe num outro sujeito.

Trata-se aqui das seis restantes categorias, a saber, lugar, tempo, posição, estado (ou posse), acção e paixão. O lugar, por exemplo, é considerado num sujeito não por este em si mesmo ou pelas suas dimensões enquanto substância (por outra coisa que se considera nesse sujeito), mas pelo lugar continente, ou seja, por um outro sujeito (cf. 2, 56). Assim, a noção formal destes entes tem uma origem extrínseca, mas alcança a formalidade da sua natureza no sujeito em termos do qual eles inerem; a noção de ente realiza-se neles pela sua relação final com a substância na qual existem, pelo que se reduzem em modo $e$ causa aos entes do terceiro tipo (cf. 2, 57-8).

Teodorico termina este segundo capítulo mostrando porque razão estes entes que são tomados a partir da noção formal e definitiva de uma substância não constituem um género de categoria distinto do género da substância em termos da própria noção:

1) se tomados da noção da substância em termos da sua quididade, os entes são acidentes próprios e paixões essenciais da substância, pelo que pertencem ao género desta como propriedades $(\rightarrow$ Tipo I);

2) se forem tomados a partir da noção de outro género, os entes são

2.1) propriedades, se não se considerar a noção do sujeito ( $\rightarrow$ Tipo II);

2.2) modos e determinações da substância, em relação ao sujeito $(\rightarrow$ Tipos III e IV).

Os modos de principiar ou originar um ente podem agora ser esquematizados para melhor compreensão dos dois primeiros capítulos deste tratado: 
Quadro 3

\begin{tabular}{|c|c|c|c|c|}
\hline & \multicolumn{4}{|c|}{ Teoria de Teodorico de Freiberg em De origine rerum praedicamentalium } \\
\hline $\begin{array}{l}\text { Categorias } \\
\text { aristotélicas }\end{array}$ & $\begin{array}{l}\text { Modi princi- } \\
\text { piandi entis }\end{array}$ & \multicolumn{3}{|l|}{ Entes } \\
\hline \multirow{3}{*}{$\begin{array}{l}\text { S } \\
\text { U } \\
\text { B } \\
\text { S } \\
\text { T } \\
\hat{A} \\
\text { N } \\
\text { C } \\
\text { I } \\
\text { A }\end{array}$} & \multirow{2}{*}{$\begin{array}{l}\frac{\text { Modo 1 }}{\text { Causas final e }} \\
\text { eficiente: } \\
\text { Princípios ex- } \\
\text { trínsecos }\end{array}$} & \multirow[b]{2}{*}{$\begin{array}{l}\text { ENTES } \\
\text { NATURAIS }\end{array}$} & \multicolumn{2}{|c|}{$\begin{array}{l}\text { As inteligências, sem acidentes, aptas pela sua essência e originariamente a } \\
\text { subsistir com relação a um fim e a participar da perfeição do seu fim }\end{array}$} \\
\hline & & & \multicolumn{2}{|c|}{$\begin{array}{l}\text { Entes não originariamente aptos a alcançar a perfeição do seu fim a não ser } \\
\text { por meio de uma qualquer transmutação alteradora e geralmente movente } \\
\text { em si próprios: necessitam da quantidade contínua e da qualidade (cf. } \\
\text { Modo 3, Tipo II) }\end{array}$} \\
\hline & $\begin{array}{l}\text { Modo } 2 \\
\text { Causas formal } \\
\text { e material: } \\
\text { Princípios } \\
\text { intrínsecos }\end{array}$ & \multicolumn{3}{|c|}{$\begin{array}{l}\text { SUBSTÂNCIAS (simples ou compostas), ou ENTES NUM SENTIDO ABSOLUTO (um ente é ente } \\
\text { num sentido absoluto graças à sua essência e é livre de todo o acidente pelo qual um ente } \\
\text { se encontra votado ao movimento) }\end{array}$} \\
\hline \multirow{7}{*}{$\begin{array}{l}\text { A } \\
\text { C } \\
\text { I } \\
\text { D } \\
\text { E } \\
\text { N } \\
\text { T } \\
\text { E } \\
\text { S }\end{array}$} & \multirow{7}{*}{$\begin{array}{l}\frac{\text { Modo } 3}{\text { "Modo inomi- }} \\
\text { nado": } \\
\text { um ente toma } \\
\text { a noção da sua } \\
\text { entidade a par- } \\
\text { tir de princípios } \\
\text { simultaneamen- } \\
\text { te extrínsecos e } \\
\text { intrínsecos }\end{array}$} & \multirow[t]{7}{*}{$\begin{array}{l}\text { Entes que } \\
\text { existem em } \\
\text { substâncias: } \\
\text { os "ACIDEN- } \\
\text { TES" }\end{array}$} & \multirow{2}{*}{$\begin{array}{l}\text { Tipo I: algo pertence a } \\
\text { um ente segundo a no- } \\
\text { ção formal e definitiva } \\
\text { do ente a que pertence, } \\
\text { nomeadamente em ter- } \\
\text { mos da sua quididade = } \\
\text { PROPRIEDADES }\end{array}$} & $\begin{array}{l}\text { Tipo I.1: segundo a noção formal de uma coisa de } \\
\text { modo essencial e absoluto } \\
\text { Ex.: o uno e o múltiplo; o igual e o dissemelhante }\end{array}$ \\
\hline & & & & $\begin{array}{l}\text { Tipo I. 2: segundo a noção da essência de uma } \\
\text { coisa, mas em relação a outra coisa } \\
\text { Ex.: a causa e o causado }\end{array}$ \\
\hline & & & \multirow{2}{*}{$\begin{array}{l}\text { Tipo II: Um ente é algo } \\
\text { de um ente de acordo } \\
\text { com esse mesmo ente } \\
\text { como sujeito = Pro- } \\
\text { PRIEDADES NATURAIS; } \\
\text { DETERMINAÇÕES Ou } \\
\text { DISPOSIÇÕES NATU- } \\
\text { RAIS }\end{array}$} & $\begin{array}{l}\text { Tipo II.1: QUALIDADES reais (princípios num modo } \\
\text { essencial e originário) }\end{array}$ \\
\hline & & & & $\begin{array}{l}\text { Tipo II.2: } \text { OUANTIDADE e movimento local (princí- } \\
\text { pios num modo essencial mas não originário) }\end{array}$ \\
\hline & & & \multirow{2}{*}{$\begin{array}{l}\text { Tipo III: Um ente é algo } \\
\text { de um ente segundo } \\
\text { esse mesmo ente-sujeito } \\
\text { e segundo outra coisa } \\
\text { que existe nesse mesmo } \\
\text { sujeito = } \underline{\text { RELAĊ̃̃O }}\end{array}$} & $\begin{array}{l}\text { Tipo III.1: se tomam a sua entidade de um outro } \\
\text { segundo a noção formal deste, então são proprie- } \\
\text { dades de uma coisa natural ( } \rightarrow \text { Tipo I) }\end{array}$ \\
\hline & & & & $\begin{array}{l}\text { Tipo III.2: se tomam a sua entidade a partir de uma } \\
\text { outra coisa que se encontra numa substância, são } \\
\text { entes classificáveis num género pelo facto que a } \\
\text { coisa de acordo com cuja noção formal e definitiva } \\
\text { são tomados é uma determinação natural de uma } \\
\text { substância ( } \rightarrow \text { Tipo II) }\end{array}$ \\
\hline & & & 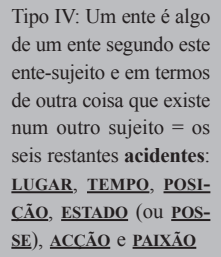 & $\begin{array}{l}\text { Reduzem-se ao mesmo modo e à mesma causa } \\
\text { em género do Tipo III }\end{array}$ \\
\hline
\end{tabular}

Modos de Principiar os Entes e Respectivos Tipos de Entes (as Categorias Aristotélicas) segundo Teodorico de Freiberg 
De realçar é a redução que Teodorico opera dos quatro tipos originais do Modo 3 a somente dois, a saber, I e II. Ou seja, aquilo que comummente se chama os acidentes são ora propriedades de uma coisa natural ou de uma substância (Tipo I), ora determinações ou disposições naturais de uma substância (Tipo II). Esta redução, porém, fora já anunciada em 1, 24. 


\section{SOBRE A ORIGEM DAS COISAS CATEGORIAIS DE TEODORICO DE FREIBERG}

\section{Introdução}

(1) Como nos diz o Filósofo nas suas Refutações Sofísticas ${ }^{12}$, quando não se conhecem as coisas comuns ${ }^{13}$, falta-nos forçosamente o conhecimento das coisas individuais ${ }^{14}$. As mais comuns ${ }^{15}$ de todas são o ente e as coisas que pertencem ao ente por essência ${ }^{16}$. Refiro-me às coisas que pertencem ao ente por essência

\section{Aristóteles, Soph. el. I, 1, 164a21-2.}

13 As coisas que se predicam de todas as outras, por oposição aos entes individuais (ens commune vs. ens particulare).

${ }^{14}$ Esta frase introdutória diz-nos de imediato duas coisas fundamentais acerca deste tratado: primeiro, que para se proceder à fundação das ciências particulares (ou seja, ciências das coisas individuais) temos que ter conhecimento acerca das propriedades ou determinações que são comuns a todas as coisas na medida em que são entes, coisas existentes; em segundo lugar, ao invocar Aristóteles, Teodorico informa-nos que se posiciona numa via de investigação metafísica de raiz aristotélica. De facto, e em relação a este segundo aspecto, tanto a Metafísica de Aristóteles como o comentário da mesma por Averróis serão constantemente invocados ao longo do tratado.

15 Os sublinhados, em itálico e/ou negrito, são nossos.

16 Algo pertence a um ente por essência (per se) ou por acidente (per accidens), ou seja, algo pertence à essência de um ente de modo tal que ele não seria o mesmo ente sem isso, ou algo é extrínseco à essência de um ente, não lhe sendo indispensável para a sua existência (esse). Pela mesma razão, o ente que é por essência ou essencialmente é um ente em si ou por si mesmo (ens per se), existindo por si sem necessitar de mais nada para esse fim, enquanto o ente que é por acidente necessita, para existir, de um ente que é um ente em si mesmo: ele inere (inest) num ente em si mesmo, pelo que, mais que um ente, ele é um ente de um ente (ens entis). Esta é a opinião ortodoxa representada por Tomás de Aquino (ex.: Accidens dicitur magis entis, quam ens. [Summa theol. I, q. 90, a. 2, co.; cf. ainda ibid., q. 45, a. 4, co.; ibid. I-II, q. 110, a. 2, ad 3]) e com a sua fonte na metafísica aristotélica que divide a realidade entre a substância, a ov̉ $\sigma^{\prime} \alpha$, aquilo que é por essência ou por si mesmo ( $\kappa \theta^{\prime}$ ' $\left.v^{\tau} o^{\prime}\right)$, e aquilo que se predica dela ou que a caracteriza sem porém a afectar

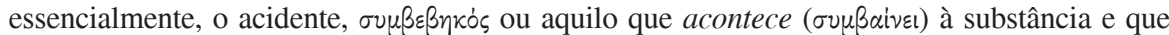
se chama um ente somente na medida em que é uma determinação (qualidade, afecção, etc.) de um ente em si mesmo, pois que em si mesmo não tem uma existência própria nem pode ser separado da substância (cf. Met. VII, 1, 1028a10-31). Vemos aqui a divisão das categorias aristotélicas numa lista problematicamente desigual entre a substância e os seus acidentes. Tendo este quadro em mente, a tradução de ea, quae sunt entis per se no texto acima poderia ser "os entes (ou coisas) que pertencem ao ente em si mesmo", mas a problemática do presente texto reside em grande medida no facto de Teodorico considerar os acidentes também como entia per se, como entes de pleno direito, pelo que a tradução "as coisas que pertencem ao ente por essência", com por essência a qualificar pertencem (sem contudo deixar de qualificar também $o$ ente), parece ser mais correcta. 
seja como partes do ente, seja como paixões essenciais e acidentes próprios do ente enquanto ente ${ }^{17}$.

(2) Mas as primeiras partes do ente são os géneros das coisas categoriais ${ }^{18}$. Assim sendo, devemos de algum modo reflectir sobre elas de forma geral, isto $e ́$, sobre a origem e a natureza ${ }^{19}$ das coisas categoriais.

(3) E porque muitos muito disseram, e de igual modo <muito> escreveram sobre isto, e visto que até hoje todos acharam por bem escrever sobre este assunto, tal tendo-lhes sido permitido, também eu, reflectindo ${ }^{20}$ humildemente e de modo meramente especulativo acerca da difícil tarefa de um exercício doutrinal, cuidei em não deixar de fazer a vontade de alguns amigos que me pediam que lhes escrevesse um memorando sobre este assunto; o que fiz sem qualquer asserção definitiva e sem prejuízo de melhor opinião, meramente de modo perscrutador para que seja uma matéria de interrogação e de investigação em comum para eles e para mim, e para, se tal nos for de algum modo possível, chegarmos a algo de verdadeiro na dificuldade tão obscura deste assunto.

(4) A exposição da presente reflexão divide-se em cinco partes.

(5) Na primeira trata-se da origem das coisas categoriais em geral e, simultaneamente com isto, da natureza e da origem da substância em particular.

(6) Na segunda, da origem dos entes que existem ${ }^{21}$ numa substância e, de um modo geral, de todos os géneros distintos da substância.

(7) $\mathrm{Na}$ terceira expõe-se a natureza comum dos entes que são classificáveis num género e porque razão alguns são excluídos da classe dos géneros.

(8) $\mathrm{Na}$ quarta mostra-se algo que foi previamente suposto, a saber, de que modo o ente começa por diferir formalmente do nada ou do não-ente, e nela encontrarás algumas considerações sobre a unidade e a ordem das formas.

(9) Na quinta mostra-se algo que foi igualmente suposto previamente, a saber, como o intelecto tem o modo de um princípio causal em relação a alguns entes na medida em que alguns são entes de intenção primeira, constituídos por uma operação do intelecto de acordo com os filósofos e sobretudo com os peripatéticos, cuja opinião, na medida em que pude compreendê-la, levei em conta na reflexão sobre este assunto.

${ }^{17}$ Cf. Aristóteles, Met. VII, 1, 1028a18-20.

18 Res praedicamentales. A expressão res praedicamentalis, significando em termos gerais categoria, é de uso raríssimo e meramente esporádico; exceptua-se os Quodlibeta de Godofredo de Fontaines, onde a expressão aparece várias vezes. O uso abundante que Teodorico dela fez no presente tratado não alterou esta situação, com a expressão a aparecer apenas muito esporadicamente em textos posteriores. Traduz-se aqui res praedicamentalis à letra como coisa categorial, pois que a intenção de Teodorico é a de mostrar que as categorias são também elas coisas reais, ou seja, não meras coisas de razão.

${ }^{19}$ Ratio. Por ratio pode-se entender um leque alargado de conceitos metafísicos que vão da natureza, noção, ou conceito, à causa ou fundamento; ratio, essentia e definitio são frequentemente sinónimos, nomeadamente quando ratio traduz o grego $\lambda$ ó yos.

${ }^{20}$ Note-se o uso figurativo do verbo ruminare, ruminar.

${ }^{21} \mathrm{Ou}$ inerem (inesse). 


\section{Capítulo 1}

(Sobre a origem das coisas categoriais em geral e, juntamente com isto, sobre a natureza e a origem da substância em particular)

(1) O modo de principiar ${ }^{22}$ ou originar um ente ${ }^{23}$, de acordo com o qual este mesmo ente depende essencialmente desse mesmo principio, é triplo. Por "ente" 24 quero aqui dizer aquilo que é em si e que é completo em acto, em termos do acto que lhe pertence de acordo com o seu próprio género; quero também dizer aquilo que na sua essência, e não somente segundo a designação, tem a natureza e a noção de ente. Quero aqui dizer a dependência directa considerada em termos de uma qualquer origem causal, não como naqueles entes que dependem de outros como de uma causa necessária, ou se algum outro modo existe de dependência indirecta ${ }^{25}$.

(2) Um tal ente, digo, de um modo principia ou tem origem a partir de um outro em termos de causa; o que sem dúvida faz com que este princípio causal esteja fora da essência de uma coisa, contudo unindo ${ }^{26}$ e constituindo $<$ essa $>$ coisa no seu $\operatorname{ser}^{27}$ quer no modo de um princípio eficiente, quer num modo final.

(3) De um outro modo uma coisa principia a partir desses <princípios $>$ que fazem parte da sua essência, e subsiste ${ }^{28}$ pela sua própria essência a partir destes componentes que a qualificam; a este tipo pertencem a matéria e a forma nas coisas compostas.

(4) E esta diferença entre estes dois modos é considerada pelo Comentador em Sobre o Livro $V$ da Metafísica ${ }^{29}$ onde distingue a noção de princípio, de elemento e de causa segundo aquilo que foi dito, a saber, que propriamente causas são aquelas que principiam uma coisa a partir de fora; elementos são de facto aqueles que principiam uma coisa a partir de dentro; os princípios,

22 Ou seja, o modo de criar a partir de princípios.

${ }^{23}$ Note-se que as expressões modus principiandi entis e modus initiandi entis são incomuns.

${ }^{24}$ Aquilo que é. Ens traduz o grego őv, particípio presente neutro singular do verbo हival, ser. Teodorico especifica aqui o uso que faz deste termo. Modos específicos do ente abordados neste tratado são o ens per se (ver acima), o ens hoc ut hoc, este ente enquanto isto, e o ens ut nunc, o ente concreto e actual.

25 Por causa de um ente Teodorico entende aqui aquilo do qual um ente depende em termos da sua origem enquanto ente, ou seja, uma causa originária.

${ }^{26}$ No sentido de juntar num todo, reunir.

27 Ou na sua existência (esse).

28 Subsistere: termo fundamental da ontologia medieval indicando a permanência de um ente no tempo; mais concretamente, o termo denota a existência independente de uma coisa (ex.: illa enim subsistere dicimus, quae non in alio, sed in se existunt; Tomás de Aquino, Summa theologiae I, q. 29, a. 2, co.). A relação com o termo substantia, aquilo que existe pela sua própria essência - e como tal não é predicado de uma outra coisa -, é clara. (Para uma confrontação entre subsistere e substare, cf. adiante).

${ }^{29}$ Averróis, In Aristotelis Met. V. comm. 4, ed. Ponzalli, 83. 
contudo, são aqueles que dão origem a uma coisa tanto a partir de fora como de dentro.

(5) Há ainda um terceiro modo no qual algo toma a noção da sua entidade a partir de uma outra coisa, um modo decerto inominado - dê-se-lhe o nome que se quiser, desde que ele se adeqúe à sua noção e à sua verdade. A maior parte das vezes vemos este modo ser considerado em termos de uma analogia, como se verá abaixo. Este modo é aquele segundo o qual algo é o princípio de uma outra coisa de tal maneira que graças a esse mesmo princípio existindo fora da essência daquilo do qual é o princípio, graças a esse mesmo princípio subsiste contudo formalmente aquilo do qual é o princípio na medida em que toma desse mesmo princípio, a partir do seu próprio conceito, a noção da sua entidade ou quididade ${ }^{30}$. Pelo que pertence à definição ${ }^{31}$ desse ente exprimindo aquilo que ele é enquanto ente ${ }^{32}$. Deste modo são as coisas que pertencem a um género distinto da substância enquanto são entes, ${ }^{33}$ como abaixo se mostrará, onde se distinguirá este modo.

(6) A noção do ente é diferente de acordo com estes três modos, de acordo com o que um ente é reduzido ${ }^{34}$ a um destes princípios.

${ }^{30}$ Quiditas, a definição completa de uma coisa, o conjunto dos seus atributos essenciais; a resposta à questão "o que é", quid sit, acerca de uma coisa (por oposição à questão se ela é, an sit).

31 A definitio é um outro termo fundamental da ontologia medieval, indicando a noção (ratio) significando (dizendo; exprimindo) aquilo que uma coisa é. Traduz o grego ópı $\sigma$ ós

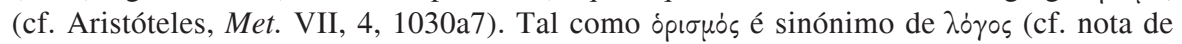
J. Tricot em Aristóteles, La métaphysique, vol. I, Paris, Vrin, 1970, p. 362), definitio e ratio também se podem intercambiar.

32 Parafraseando esta longa e complexa passagem: algo extrínseco a uma coisa (ou seja, não fazendo parte da sua essência) é, contudo, o princípio a partir do qual ela subsiste formalmente na medida em que ela adquire a sua entidade ou quididade a partir desse princípio devido à sua própria significação ou conceito (intellectus), por outras palavras, ao entendimento que temos dela; isto quer dizer que a dependência de uma coisa deste tipo é tal que o princípio do qual depende, embora não seja um elemento da sua essência, tem que fazer parte da sua definição (cf. acima o significado deste termo). Este é o modo no qual as determinações categoriais têm a sua origem na substância. Note-se aqui o uso de intellectus significando conceito (traduzindo o grego vóntov, aquilo que é pensado) por oposição ao seu uso mais comum significando intelecto (voû, , em grego) ou acto de intelecção (ou seja, pensamento; cf. grego vónбıs) (cf. Tomás de Aquino, De veritate q. 17, a. 1, co.: hoc nomen intellectus quandoque significat rem intellectam, sicut nomina dicuntur significare intellectus; quandoque vero ipsam intellectivam potentiam; quandoque vero habitum quemdam; quandoque etiam actum.).

${ }^{33} \mathrm{Ou}$ seja, as outras categorias.

34 Atente-se na etimologia de reducere, indicando os significados de reconduzir, reenviar, restabelecer; assim se explica o sentido técnico de reducitur como reenviar/atribuir às causas ou aos princípios originários. 
(7) De facto, se se considerar o ente em termos dos seus princípios intrínsecos - e isto com respeito ao segundo modo acima designado ${ }^{35}$-, então, e de modo absoluto, uma coisa tem formalmente em si a noção de ente, a qual é a primeira de todas as intenções ${ }^{36}$ e graças à qual uma coisa começa por diferir formalmente do nada. Pois quando se diz que algo é um ente, mais não há do que a explicação formal do próprio ente em termos daquele < princípio $>$ intrínseco do mesmo graças ao qual uma coisa subsiste formalmente e em termos do acto ${ }^{37}$, e o qual é a forma nas coisas compostas ou a simples essência em acto nas coisas simples.

(8) Acerca das quais essências simples diz o Filósofo no livro VIII da Metafi$\operatorname{sica}^{38}$ que naquelas nas quais não há matéria, sensível ou inteligível, cada ente é imediatamente uno e um ente como aqueles que não pertencem ao $<$ seu $>$ género: o que não é outra coisa senão que cada um destes entes simples em termos da sua essência é uno e um ente, não tendo misturada < às suas causas intrínsecas> nenhuma causa extrínseca. O que é igualmente verdade relativamente aos entes compostos na medida em que cada um deles subsiste formalmente em termos dos seus princípios intrínsecos, embora pelo facto de passarem da potência ao acto tenham misturada uma causa extrínseca, como diz o Filósofo no mesmo texto ${ }^{39}$. Razão pela qual o Comentador diz em Sobre o Livro XI da Metafísica ${ }^{40}$, onde o Filósofo ${ }^{41}$ faz a distinção entre as causas intrínsecas, a matéria e a forma, e as causas extrínsecas, o fim e a causa eficiente, de acordo com o facto de estas antecederem a coisa e aquelas serem simultâneas à coisa: "As causas pelas quais uma coisa se torna um ente e uma unidade são juntamente com aquilo que por causa delas se torna duma só vez o todo, visto que têm uma determinação tal no composto como as partes no todo. "42

35 Cf. $1,3$.

${ }^{36}$ A intenção, intentio, é um dos conceitos mais complexos da metafísica medieval. De um modo geral, a intentio exprime a tensão da mente em direcção a uma coisa ou a uma acção, pelo que a sua significação pode ir de conceito, em termos mais estritamente lógico-metafísicos, a desígnio ou propósito, em filosofia moral. Neste tratado trata-se precisamente da perspectiva original de Teodorico sobre a distinção lógico-metafísica entre as intenções primeiras e segundas, ou os conceitos de "coisas" (ex.: homem, correr) e os conceitos de conceitos (ex.: substantivo, verbo): segundo ele, e contrariamente à opinião corrente no seu tempo e antes dele, nem todas as criações do intelecto, as ditas coisas de razão (res rationis), são coisas de intenção segunda, pois que o poder criativo do intelecto é fundador de realidade concreta. Ver abaixo um desenvolvimento desta distinção fundamental do pensamento medieval.

37 Em acto.

38 Aristóteles, Met. VIII, 6, 1045a36-b1, 1045b5-6.

39 Aristóteles, Met. VIII, 6, 1045b20-22.

${ }^{40}$ Averróis, In Aristotelis Met. XII, comm. 16, Venetiis 1562, 302vH.

${ }^{41}$ Aristóteles, Met. XII, 3, 1070a21-22.

42 Teodorico mostra que as coisas compostas e as simples são ontologicamente idênticas na medida em que subsistem pelos seus princípios intrínsecos; que as coisas compostas de matéria e forma tenham causas extrínsecas pelo facto de passarem da potência ao acto, tal não altera o seu estatuto ontológico que é, como veremos, o de substância. 
(9) Assim, diz-se de algo que é um ente num sentido absoluto graças à sua essência em termos dos seus princípios intrínsecos. E porque nestes termos um ente não contém nenhuma causa ${ }^{43}$, eis porque é livre de todo o acidente importando ${ }^{44}$ uma qualquer natureza ou coisa determinando a essência mesma de uma coisa graças à qual uma coisa se encontra de algum modo votada ao movimento ${ }^{45}$. E a razão disto é que cada um destes acidentes é uma forma e o acto de um ente que é uma substância, ainda que de modo acidental; assim, a relação que a substância tem com esta forma é a relação que aquilo que existe em potência tem com o acto. Contudo, nada de tal se pode actualizar a si próprio; eis porque uma substância de acordo com a noção em virtude da qual é um ente num sentido absoluto graças à sua essência não é a causa de tais acidentes senão em termos de matéria e de sujeito ${ }^{46}$. Assim, estas formas ocorrem numa substância graças a uma causa extrínseca à essência daquilo que é o sujeito de tais acidentes, nomeadamente por meio de um gerador, caso sejam acidentes essencialmente, ou, se não forem tal, de qualquer outro modo por meio de um motor. E o Filósofo afirma isto no Livro I da Física ${ }^{47}$ onde diz que a matéria juntamente com a forma é a causa dos entes que existem nas substâncias, como a mãe. A mãe não é um princípio na geração senão graças a uma faculdade mais formal, a qual pertence ao agente; do mesmo modo os acidentes não se encontram numa substância senão graças a um outro princípio extrínseco ao sujeito ${ }^{48}$.

(10) Assim, sejam quais forem os entes que existem num ente de modo absoluto em termos da essência, tal ocorre na exclusão de toda a causa extrínseca; e por causa disto, propriamente falando, estes entes não têm outra causa real senão a essência da coisa na qual existem, tal como no caso do uno e do múltiplo e das suas diferenças ${ }^{49}$.

(11) E daqui se segue ainda que tais coisas não importam nenhuma natureza ou coisa natural acrescentada à essência, nem são propriamente acidentes, mas propriedades de uma coisa, sem as quais uma coisa não é algo de melhor, como se diz no Livro II da Física ${ }^{50}$ mas aquilo que graças a elas se diz ser uma

43 Ou seja, nenhum princípio extrínseco (cf. acima 1, 4)

${ }^{44}$ No sentido de trazer consigo, acarretar, introduzir.

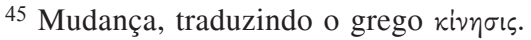

${ }^{46}$ No sentido metafísico do termo, subiectum traduz o particípio presente neutro grego

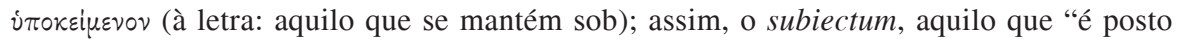
sob" (cf. o verbo subiecere), é a substância enquanto substrato dos acidentes.

47 Aristóteles, Phys. I, 9, 192a13-14.

48 Teodorico argumenta aqui que embora as substâncias enquanto sujeitos possam ter acidentes, tal deve-se a causas extrínsecas a elas, nomeadamente a um gerador, no caso dos acidentes essenciais, ou a um motor, no caso de acidentes inessenciais.

49 Visto que, como se viu, a existência da substância é absoluta em termos da sua essência, excluindo quaisquer causas extrínsecas, se nelas existem outras coisas, então estas coisas existem nela graças à sua essência. Não se trata pois de acidentes, segundo 1,9 , mas sim de propriedades da substância $(1,11)$.

50 Aristóteles, Phys. II, 2, 194a3-7. Teodorico refere-se aqui aos acidentes que Aristóteles indica como independentes do movimento, a saber, de um lado, o ímpar, o par, o recto, o curvo, de outro lado, o número, a linha, a figura. 
coisa é essencialmente em termos da sua quididade e da sua essência. Mas o mesmo não se passa no caso das coisas naturais, no qual a noção do bom e do apropriado na natureza é considerada a partir de alguns acidentes acrescentados a uma substância em termos do fim, relativamente ao qual um agente produz tais acidentes num sujeito ${ }^{51}$.

(12) É pois evidente qual é a noção do ente conforme <este> se considera como subsistindo somente em termos dos seus princípios intrínsecos, ou seja, que somente de acordo com isto ${ }^{52}$ ele tem formalmente a noção de ente; e este modo primeira e essencialmente convém à substância. Logo, reflectir sobre este ente e as suas propriedades nestes termos é uma tarefa que compete ao metafisico ${ }^{53}$.

(13) Se, contudo, se considerar uma coisa com relação às suas causas, e isto quanto ao primeiro dos modos acima designados ${ }^{54}$, então ela deixa de partilhar a dita noção de ente. Pois de acordo com isto diz-se que algo é um ente enquanto emanando de algum princípio produtivo ${ }^{55} \mathrm{em}$ vista de um $\mathrm{fim}^{56}$. E de acordo com isto tem quer o carácter quer a designação de natural pelo sentido lato do termo "natural", de modo que se entenda a natureza não somente enquanto princípio do movimento e do repouso, como na Física ${ }^{57}$, mas se entenda por natureza aquilo que é princípio, sujeito ou termo de uma qualquer operação real, de acordo com o qual os entes separados se chamam coisas naturais. E de acordo com isto todo o ente, com relação às suas causas, se diz ser uma coisa natural, nomeadamente na medida em que é a partir de um acto natural com vista a algum fim <estabelecido> pela natureza, no qual participa pela sua operação natural: de facto, o agente não age essencialmente senão com a intenção de um fim; de outro modo a sua acção seria por mero acaso, segundo se diz no livro II da Física ${ }^{58}$.

(14) Se, pois, uma tal coisa for pela sua essência originariamente apta a subsistir com relação a um fim e a participar na perfeição do seu fim, o tipo de coisas que os filósofos ${ }^{59}$ consideravam ser certos entes aos quais chamavam

51 O bom e o apropriado são acidentes das coisas naturais na medida em que são “importados” para a coisa pelos princípios extrínsecos (o fim e o eficiente).

${ }^{52} \mathrm{Ou}$ seja, sem necessitar de mais nada.

53 Conclusão da exposição em 1, 7-12: aquilo que subsiste somente em termos dos seus princípios intrínsecos é a substância, a primeira das categorias considerada na lista aristotélica.

${ }^{54}$ Cf. $1,2$.

55 Ou seja, uma causa eficiente.

${ }^{56}$ Uma causa final. Estamos, pois, agora no âmbito dos princípios extrínsecos, ou causas, segundo a terminologia de Averróis (cf. acima 1.4) adoptada por Teodorico. Segundo este, a introdução destes princípios extrínsecos implica uma noção de ente diferente relativamente àquela dos entes que só contêm princípios intrínsecos (cf. 1,7 - 12).

57 Aristóteles, Phys. II, 1, 192b20-23.

58 Aristóteles, Phys. II, 8, 198b34-199a12.

${ }^{59}$ Ex.: Liber de causis, prop.7 - 13, ed. Pattin, 149-64; Proclo, Elem. theol., prop. 
inteligências, nestes entes, digo, não haverá nenhum acidente pois, como se diz no livro II de Do Céu e do Mundo, ${ }^{60}$ todo o ente é em vista da sua própria operação. De facto, a operação é o fim interno, em virtude do qual um ente participa directamente na perfeição do $<$ seu $>$ fim. Se, pois, existirem tais entes, como acreditavam os filósofos, e segundo eles ${ }^{61}$ estes são pela sua essência o princípio da sua operação, não haverá neles qualquer natureza extrínseca à sua essência, à qual natureza pertencem os acidentes: em vão seriam os entes que a natureza não permite. Assim, o Comentador fala do seguinte modo em Sobre o Livro XII da Metafísica"2: "Devemos saber que as substâncias são de dois modos: um modo no qual é impossível escapar aos acidentes e um outro modo sem qualquer acidente; o primeiro modo é sensível, o segundo é inteligível. " $E$ fala $a^{63}$ das substâncias separadas de acordo com a sua e a opinião de outros filósofos.

(15) Mas se existirem entes tais que não são originariamente aptos a alcançar a perfeição do seu fim a não ser por meio de uma qualquer transmutação alteradora e geralmente movente em si próprios, em todos estes entes é necessário encontrar outras naturezas extrínsecas à sua essência, as quais são os princípios de tais movimentos quer activa, quer passivamente ${ }^{64}$.

(16) Mas os princípios de tais movimentos são essencial e imediatamente

20, ed. Vansteenkiste, 273; ibid., prop. 166-183, ed. Vansteenkiste, 514-521; Avicena, Metaph. IX, 5, Venetiis 1508, 104v - 105r; Averróis, In Aristotelis Metaph. XII, comm. 38, Venetiis 1562, 321rF - vG; ibid., XII, comm. 51, 336rD, 336vL - M.

60 Aristóteles, De caelo II, 3, 286a8-9.

${ }^{61}$ Cf. Liber de causis, prop. 8, comm., ed. Pattin, 152; ibid., prop. 13, ed. Pattin, 162-64; Proclo, Elem. theol., prop. 167-168, ed. Vansteenkiste, 514-515; Avicena, Metaph. IX 4, Venetiis 1508, 104vaA.

62 Averróis, In Aristotelis Met. XII, comm. 25, Venetiis 1562, 310rB.

${ }^{63}$ Averróis, In Aristotelis Met. XII, comm. 25, Venetiis 1562, 310rB-E.

64 Teodorico, embora apoiando-se mais directamente em Averróis, segue aqui a doutrina exposta no livro XII da Metafísica: a substância é a primeira parte ( $\pi p \omega \hat{\tau} \tau o v$

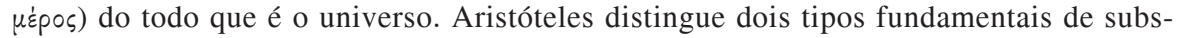
tância, sensivel (que apresenta dois tipos, a substância eterna e a substância corruptível) e imóvel, a primeira envolvendo o movimento e logo objecto da física, e a segunda constituindo o objecto da metafísica; seguem-se à substância a qualidade e a quantidade, as quais não existem separadamente da substância e não são propriamente entes, mas sim qualidades e movimentos da substância (cf. Aristóteles, Met. XII, 1, 1069a181069b2). Assim, em 1, 14, Teodorico fala daquilo que corresponde em Aristóteles à substância imóvel, que Averróis denomina inteligível, e em 1, 15 aborda a substância sensível; nas secções seguintes Teodorico abordará também a qualidade e a quantidade. Contudo, note-se que Teodorico se apoia mais directamente em Averróis na medida em que neste se mostra mais claramente o papel dos acidentes na distinção das substâncias sensível e inteligível. 
qualidades. Para o que é necessário que a translação ${ }^{65}$ tenha antecedência ${ }^{66}$ no caso das coisas naturais ${ }^{67}$.

(17) Contudo, antes de mais nada é necessária a quantidade contínua em todas as coisas activas e passivas e geralmente moventes de acordo com a natureza. De facto, é preciso que o agente e o paciente sejam simultâneos, como se diz no livro I de Acerca da Geração e da Corrupção ${ }^{68}$; é mesmo necessário que eles tenham distinção e extensão nas suas partes, o que ocorre graças à quantidade, pelo que a quantidade, de acordo com o seu género, é o primeiro de todos os acidentes na natureza. Assim, e por esta razão, em relação a um primeiro contínuo movido ${ }^{69}$, primeira e maximamente convém ao primeiro corpo $^{70}$ ser uma grandeza contínua, como diz o Filósofo no princípio do livro $\mathrm{X}$ da Metafísica ${ }^{71}$.

(18) Esta é pois a razão e a intenção da natureza em constituir esses acidentes que importam alguma coisa natural. Daqui resulta que, se há alguns entes, ditos acidentes, que não são princípios de uma qualquer operação natural ou real, como são certas relações ${ }^{72}$ e isso mesmo que é o lugar e certos outros, estes não são <fruto > de um acto natural ${ }^{73}$. Pois a natureza não age senão em relação a um fim, o qual é uma certa natureza e o qual uma coisa alcança pela sua operação natural ou real.

(19) Mas como nos entes não há senão dois tipos de princípios, a saber, a natureza e o intelecto, se tais entes não são constituídos por um acto natural,

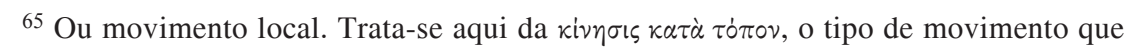
Aristóteles denomina фopd́.

${ }^{66}$ Em relação a outros tipos de movimento.

${ }^{67}$ Esta antecedência deve-se ao facto de, segundo Aristóteles, todas as substâncias sensíveis - ou seja, mesmo as eternas, como as esferas celestes - estarem sujeitas ao movimento local ou translação, enquanto as substâncias eternas não estão sujeitas aos outros tipos de movimento ou mudança. A leitura destes parágrafos deve ser feita à luz da teoria aristotélica da mudança, $\mu \varepsilon \tau \alpha \beta \gamma \lambda \dot{\eta}$, desenvolvida sobretudo na Física (III, 1, 200b32; V, 1 e passim) e na Metafísica (VII, 7 e VIII, 2): em traços gerais, a mudança divide-se em 1) geração e o seu contrário, corrupção ( $\gamma^{\dot{\varepsilon} v \varepsilon} \varepsilon\llcorner\varsigma$ e $\phi . \vartheta \rho \dot{\alpha})$, ou geração simpliciter e 2) geração secundum quid (relativa a algo), ou movimento ( $\kappa i v \eta \sigma \varsigma)$, o qual se subdivide em três subtipos de acordo com as categorias envolvidas: 2.1) o movimento em termos de

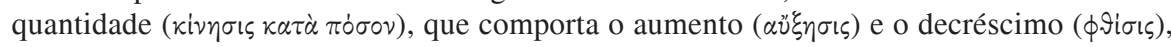
2.2) o movimento em termos de qualidade (

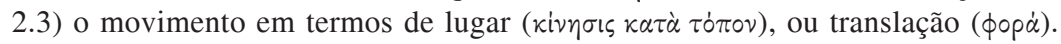

68 Aristóteles, De gen. et corr. I, 7, 323b31-33.

${ }^{69} \mathrm{Ou}$ seja, o paciente, o corpo que sofre a acção do agente movente.

$70 \mathrm{O}$ agente, o corpo que primeiro move os outros corpos.

71 Aristóteles, Met. X, 1, 1052a26-28.

72 Relativae habitudines.

${ }^{73}$ Teodorico procede aqui a uma primeira - e provisória - divisão no que diz respeito aos nove "acidentes" da lista aristotélica das categorias: só a quantidade e a quantidade são fruto de uma operação natural, sendo os restantes o resultado de uma operação do intelecto (cf. 1, 19). 
então pertencem necessariamente ao outro tipo e são reduzidos ao outro tipo de causa que é o intelecto. Não, contudo, no mesmo modo como aqueles que são a partir de uma operação tal do intelecto que são coisas de intenção segunda, os quais não pertencem de modo determinado a nenhum género dos entes reais; estes são deveras coisas de intenção primeira em si de acordo com as próprias noções ordenadas num género, mais precisamente constituindo integralmente alguns dos mesmos dez géneros. Pois nem todos os entes que são a partir de uma operação do intelecto são coisas de intenção segunda, mas somente aqueles que são de um tal modo a partir de um acto do intelecto que são as formas da parte da razão sob as quais as coisas se tornam racionais, nem se considera acerca delas que sejam algo de um ente natural, pelo que, e de forma mais conveniente, se chamam coisas de intenção segunda e coisas de razão ${ }^{74}$.

(20) Mas estes entes de que falamos são a partir de um acto do intelecto de tal modo que o intelecto os determina em relação às coisas naturais como certas formas e modos de entes naturais, e isto de acordo com as diversas naturezas determinadas dos diversos géneros. Pelo que é também necessário que os entes naturais pertençam à noção definitiva ${ }^{75}$ destes como aquilo que é o mais formal na definição na medida em que são entes pelo facto de tomarem a

${ }^{74}$ A problemática das intentiones, divididas em intentio prima et intentio secunda, é fundamental para a compreensão deste texto e da metafísica escolástica. De modo introdutório, pode dizer-se que se trata dos primeiro e segundo conceitos de uma coisa, ou seja, a prima intentio é a representação de uma coisa segundo o seu próprio modus essendi, e a intentio secunda é a intelecção de uma coisa na sua universalidade ou no mundo como se encontra na pluralidade, ou seja, o universal. Veja-se, por exemplo, a definição clara e detalhada de Raúl o Bretão (Radulphus Brito, †1320): Modo primo videamus quid sit intentio prima et quid secunda, tam in abstracto et in concreto. Intentio prima universalis in abstracto est prima rei cognitio vel intellectio secundum proprium modum essendi ipsius rei. Prima autem intentio in concreto est res primo modo intellecta secundum proprium apparens vel modum essendi ipsius rei, sicut homo secundum quod intelligitur ratiocinans vel sentiens dicitur prima intentio, et sicut dico de homine sic intelligo de aliis. Secunda intentio universalis in abstracto est ratio intelligendi rem ut est in pluribus, et talis non est intellectio rei absoluta sed respectiva, quia prius est intelligere rem absolute quam est in pluribus. Et sicut dico de universali, sic intelligo de aliis interpretationibus incomplexis et attributis rei incomplexae iuxta primam operationem intellectus, sicut est praedicatum et subiectum et sic de aliis secundum diversos modos essendi ibi repertos. (Super Porph., q. 7A, ed. Pinborg, 98.57 - 100.71.) Parte da "revolução" levada a cabo por Teodorico é a rejeição da doutrina comummente aceite segundo a qual as categorias, tidas como res secundae intentionis, são meras res rationis, coisas da razão, sem uma existência real; é certo que algumas das coisas produzidas pela operação do intelecto são coisas de intenção segunda, mas estas são somente aquelas sob as quais as coisas se tornam racionais ou pensáveis (ex.: categorias gramaticais de substantivo, verbo, etc.); pelo contrário, estes acidentes produzidos pelo intelecto são deveras coisas de intenção primeira na medida em que são formas e modos de entes naturais de acordo com as diversas naturezas determinadas dos diversos géneros (cf. 1, 20).

${ }^{75}$ Que define. 
noção da sua entidade destes que são entes naturais. E porque deste modo são algo de entes reais pela natureza, que são coisas de intenção primeira, é por isso que os mesmos são coisas de intenção primeira classificados num género de acordo com as suas próprias noções, sendo o intelecto todavia o princípio constitutivo de todos eles ${ }^{76}$. Contudo, o fim não é para eles uma qualquer natureza, segundo o que a natureza se distingue face àqueles entes que estão no intelecto $^{77}$, mas o seu fim pode dizer-se uma certa perfeição que é adquirida por meio da acção do intelecto.

(21) Que tais entes são criados por uma operação do intelecto, de que modo e graças a que noção são classificados num género categorial e ainda a diferença entre eles e as coisas de intenção segunda, serão <temas $>$ tratados abaixo no princípio da segunda parte e por ordem.

(22) É assim evidente qual é a noção e o modo do ente conforme consideramos as suas causas e que tipo de entes existem ou não nele de acordo com o que subjaz às suas causas.

(23) Mas no que diz respeito ao terceiro modo mencionado de principiar coisas dependentes de algo por essência temos que saber que este modo não pode convir às substâncias. De facto, as substâncias têm em si e de modo absoluto a noção de ente completo, tanto no que diz respeito à perfeição do seu acto formal como no respeitante à perfeição do fim, sem que tal se deva a que as mesmas sejam formalmente algo de algo ou a partir de algo em termos da forma, no que consiste <precisamente> toda a noção deste terceiro modo ${ }^{78}$.

(24) Pelo que este modo só se encontra naqueles entes que existem em substâncias. Pois principiar uma coisa de tal modo que o mesmo princípio esteja

${ }^{76}$ Note-se a argumentação complexa de Teodorico (premissas marcadas com asterisco são implícitas):

(1) Os entes naturais, entes de uma operação real, são coisas de intenção primeira.

(2) Estes acidentes são constituídos pelo intelecto como formas ou modos dos entes naturais.

(3) Razão pela qual os entes naturais pertencem à sua definição.

(4) A definição de um ente é o que lhe dá a sua existência concreta ou entidade.

(5) Eles tomam assim a sua entidade destes entes naturais, que são coisas de intenção primeira.

(6)* Participam assim deste modo de ser.

$\therefore$ (7) São também eles coisas de intenção primeira.

77 Parafraseando: a natureza distingue-se do intelecto, enquanto princípio, pelo facto de no caso da primeira o fim (a causa final) ser um princípio essencial.

${ }^{78}$ Parafraseando: as substâncias não são criadas por este modo (ou seja, pelo intelecto) pois, ao contrário das coisas criadas pelo intelecto, as quais são formalmente algo pertencente a uma outra coisa ou são criadas a partir de uma outra coisa em termos de forma, as substâncias têm em si a noção de ente completo, não precisando de nenhuma outra coisa para alcançarem a perfeição do seu acto formal ou do seu fim; assim sendo, o terceiro modo de principiar um ente (cf. 1, 5), o modo do intelecto, não convém às substâncias, pelo que ficamos a saber que embora coisas de intenção primeira, estes entes de que se fala aqui não são substâncias. 
fora da essência ou da substância daquilo do qual é o princípio, sem ser nem no modo de uma causa eficiente nem de um fim, mas graças ao qual a coisa tenha formalmente a sua essência, sem contudo ser como a partir do acto ou da forma exemplificando-o, mas antes, por assim dizer, quidificando-o ${ }^{79}$, tal, digo eu, não pode convir senão àqueles entes cuja essência consiste em ser algo de algo, nomeadamente em ser um modo ou uma determinação ${ }^{80}$ de alguma substância, a qual é de facto um ente, ou em ser uma propriedade quer de uma substância quer de algo de outra natureza.

(25) E visto que todos esses entes ou são acidentes de facto ou têm o modo de um acidente, verifica-se em relação a todos eles aquilo que o Filósofo diz no princípio do livro VII da Metafisica ${ }^{81}$, <a saber,> que os acidentes são "entes porque pertencem a um ente": de facto, toda a sua entidade mais não é senão que são algo de um ente que é uma substância. E esta é a razão da analogia que é considerada entre a substância e os acidentes de facto na medida em que sustentam a categorização de um ente, como se diz no livro IV da Metafísica ${ }^{82}$. A qual analogia não é em termos de algo que acontece à substância ou ao acidente, mas de cada um deles se diz que é um ente pela sua essência. De facto, a intenção de ente é a primeira e a mais formal de todas as intenções, de acordo com a qual uma coisa é primeiramente concebida como distinguindo-se formalmente do nada. O que não pode ser por algo que possa acontecer ${ }^{83}$ a uma coisa.

(26) Logo, diz-se da substância que é um ente pela sua essência em termos de subsistência absoluta, mas diz-se de igual modo dos entes que existem nas substâncias que são entes por essência, mas com relação a uma substância ${ }^{84}$.

(27) Não como com relação a uma causa, embora tal seja verdade, a saber, que as substâncias são causas dos acidentes: diz-se de cada um que é um ente pela sua essência não envolvendo qualquer causa, como acima se disse ${ }^{85}$.

(28) Nem com relação a uma substância como a um sujeito em termos de inerência, se assim podemos dizer. De facto, a relação a um sujeito de acordo com a inerência por natureza e pelo intelecto é posterior àquilo que inere, pelo que os entes que inerem às substâncias não têm a sua entidade desta relação. De acordo com esta noção de inerência forma-se desta forma e de um sujeito um ente por acidente ou um ente relativo cujo princípio, na medida em que é um tal ente, é não só o sujeito, mas a forma inerente, mais precisamente a própria forma na medida em que a mesma é o princípio de um tal ente em termos do

79 Teodorico especifica aqui em que consiste o terceiro modo de principiar um ente, tornando a explicação algo confusa (se não mesmo suscitadora de perplexidade) de 1,5 mais clara.

80 Ou uma disposição.

${ }^{81}$ Aristóteles, Met. VII, 1, 1028a18.

${ }^{82}$ Aristóteles, Met. IV, 2, 1003b5-6.

${ }^{83}$ Ou seja, algo acidental.

${ }^{84}$ Eis pois a única diferença no estatuto ontológico entre a substância e este ente do terceiro modo.

${ }^{85}$ Cf. 1, 9-10. 
acto. Pelo que segundo Avicena ${ }^{86}$ existir num sujeito não é a essência de um acidente, mas uma sua propriedade natural.

(29) Mas diz-se de cada um deles que é um ente porque é um certo modo ou uma determinação de um ente, e isto é a essência de cada um deles ${ }^{87}$. Pelo que as definições exprimindo aquilo que cada um deles é são por adição $e$ uma coisa de uma natureza diferente é introduzida, o que não ocorre no caso das substâncias, como se mostra no livro VII da Metafísica ${ }^{88}$.

(30) Posto que na realidade não se diz nem da substância nem dos entes que existem na substância que são entes em relação às suas causas, como se disse, visto que diz-se da substância que é um ente em termos de subsistência absoluta e um ente em si em termos do acto formal intrínseco, e os entes que existem na substância não podem ter esta perfeição quanto à sua quididade e subsistência essencial, eis porque só têm a noção do ente de acordo com este terceiro modo de principiar, o qual é para estes entes que existem nas substâncias como que um complemento do segundo modo ${ }^{89}$, o qual é o mais apropriado às substâncias.

\section{Capítulo 2}

(Sobre a origem dos entes que existem numa substância e, de modo geral, de todos os géneros que se distinguem da substância)

(1) Ora, estes entes deste terceiro modo dividem-se em quatro tipos diferentes em grau e ordem conforme o grau e a ordem no modo pelo qual tomam formalmente a sua entidade de um outro ente. Visto que em comum todos têm o facto de pertencerem a um ente, tal pode ser de quatro modos.

(2) Num modo em que algo pertence a um ente segundo a noção formal e definitiva do ente a que pertence, nomeadamente em termos da sua quididade.

${ }^{86}$ Avicena, Logica I, Venetiis 1508, 9va, 1. 54-60.

${ }^{87}$ É certo que, como se disse acima $(1,26)$, estes entes do terceiro modo são entes por essência em relação a uma substância, mas esta não é uma relação causal (a substância não é uma causa deste ente) nem uma relação de sujeito em termos de inerência (este ente não inere numa substância como num sujeito), sendo simplesmente uma relação na qual este ente é um modo ou uma determinação (ou disposição) de uma substância, como já se havia afirmado.

88 Aristóteles, Met. VII, 5, 1031a1-3. Aristóteles estabelece as definições por adição

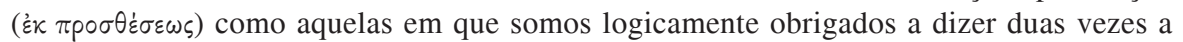
mesma coisa (cf. ao dizermos "número ímpar" repetimos duas vezes o termo número, na medida em que ao dizermos "ímpar" dizemos já "número"); para além disso, elas implicam a introdução de algo diferente da natureza, como por exemplo no caso do ímpar, o qual não se pode definir sem o número do mesmo modo que a fêmea não se pode definir sem o animal.

${ }^{89}$ Cf. $1,3$. 
(3) Num segundo modo em que é algo de um ente segundo esse mesmo ente como sujeito.

(4) Num terceiro modo segundo esse mesmo ente-sujeito ${ }^{90}$ e segundo outra coisa que existe nesse mesmo sujeito.

(5) Num quarto modo segundo estes entes de que acabámos de falar e em termos de outra coisa que existe num outro sujeito.

(6) A suficiência é evidente: um ente que depende de um outro deste modo não toma formalmente a sua entidade desse ente senão num destes quatro modos. Exemplos de casos individuais serão dados nos lugares apropriados.

(7) De facto, os entes deste terceiro tipo são aqueles que são tomados em termos de uma analogia segundo a qual são atribuídos a um sujeito. A qual atribuição convém-lhes intrinsecamente e em termos da sua essência, pelo que por essência - e não somente pela designação - a noção de ente convém deste modo aos atributos. Mas não como aqueles dos quais se diz que são alguma coisa por atribuição a algo como a um fim, como se diz da urina, de uma dieta ou do exercício físico que são saudáveis com respeito à saúde do animal, a qual é o fim, ou por atribuição a algo eficiente, como se diz da dieta ou da planta que são medicativas por atribuição ao medicinal ou à arte da medicina, a qual é propriamente o eficiente neste tipo: trata-se assim de uma predicação acidental dos atributos, pelo que não são por essência aquilo que é predicado deles segundo esta atribuição ${ }^{91}$. E distinguem-se estes três modos de analogia $<$ no comentário $>$ acerca do princípio do livro IV da Metafísica ${ }^{92}$.

(8) Assim, os entes que pertencem ao primeiro tipo ${ }^{93}$, visto que são certos modos do ente em termos da sua quididade, a saber, pela noção definitiva

${ }^{90}$ Ou seja, o ente que é sujeito.

${ }^{91}$ Segundo Teodorico, temos que distinguir claramente entre os atributos que são por essência aquilo que é predicado deles (propriedades, como ele lhes chamará no parágrafo seguinte) e aqueles que só acidentalmente o são, seja por uma analogia final (por ex., diz-se de uma dieta ou do exercício físico que são saudáveis porque promovem a saúde, ou a causa final) ou eficiente (por ex., diz-se que uma planta é medicinal por possuir virtudes curativas); estes últimos atributos são propriamente aquilo que chamamos acidentes. Teodorico continua pois fiel à dicotomia introduzida na primeira parte do tratado entre princípios intrínsecos e extrínsecos: nem a sanidade é intrínseca à dieta ou ao exercício físico, nem faz parte da quididade de uma planta ter virtudes medicinais. Isto implica uma diferença ontológica na utilização lógica do termo predicar: dizer de uma planta que ela é medicinal implica um sentido ontológico diferente do verbo ser em relação a dizer de um determinado número que é par; esta é uma predicação essencial, aquela acidental. Esta questão dos sentidos lógico-ontológicos da predicação é fundamental na problemática das categorias: estas predicam-se da substância como de um sujeito, ou seja, de modo essencial. (Ver nota seguinte.)

92 Averróis, In Aristotelis Met. IV, comm. 2; Venetiis 1562, 65rF-vI (cf. sobretudo 65vI: Praedicamenta enim attribuuntur substantiae, non quia est agens aut finis eorum, sed quia constituuntur per illam, et subiectum est eorum. Et [...] non dicuntur entia, nisi quia sunt dispositiones entis, et multi homines negant ea esse.)

93 Cf. acima 2, 2. 
exprimindo a causa ou o porquêe ${ }^{94}$ de tais entes, têm a natureza e a noção de propriedades, não sendo propriamente acidentes senão no sentido amplo do termo, na medida em que se atribui ao ente do qual são propriedades a noção de sujeito e a noção de causa é atribuída à noção formal, a qual é a noção definitiva ${ }^{95}$. Deste modo ${ }^{96}$ entende-se que estes entes têm o modo de acidentes, os quais existem num sujeito por uma causa ${ }^{97}$.

(9) Estes entes são de dois tipos. Alguns deles existem numa coisa em termos da sua essência em si e absolutamente, e todos eles implicam uma privação nessa mesma coisa ${ }^{98}$; de todos, os primeiros géneros são o uno e o múltiplo. Quero dizer que estes entes são privativos de facto. Com efeito, um ente não pode pela sua essência ser de modo absoluto em relação a si próprio a causa de uma qualquer informação ${ }^{99}$ positiva $^{100}$. A relação do ente com este modo é como a do sujeito com a forma sob cujo acto o sujeito não se pode fazer a si próprio. Contudo, um ente pode pela sua essência ser a causa da remoção de determinações extrínsecas, o que mais não é do que ser a causa de alguns modos privativos com respeito a si mesmo. Embora estes entes envolvam de facto uma privação, a razão porém por vezes investe-os de certos modos positivos, de modo que podem entender-se como sendo certos modos de um ente em termos de propriedades; e isto acontece quando são definidos a partir do próprio sujeito ${ }^{101}$; o que faz com que sejam já algo pertencente a um ente, a saber, ao próprio sujeito de acordo com a noção formal. E assim tomam formalmente a sua quididade $e$ entidade do sujeito, como por exemplo o par e o ímpar a partir do número, o igual e o desigual a partir do uno em quantidade, o igual e o diferente a partir do uno em qualidade, e por aí fora.

(10) Há porém outros entes que existem numa coisa em termos da sua essência mas com relação a outra coisa, e estes podem importar algo positivamente no seu sujeito pelo modo de uma propriedade. A razão para tal é que eles não são tomados a partir da noção da coisa-sujeito em si e absolutamente como os anteriores, mas são concebidos numa coisa a partir da relação a algum ente positivo, como são a causa e o causado, a potência activa e a potência passiva e certas relações ${ }^{102}$ e outras coisas semelhantes, se estas são coisas às quais tais modos e outros semelhantes possam convir por essência. Com efeito, estes

\footnotetext{
94 Propter quid.

95 Que define.

$96 \mathrm{Ou}$ melhor, de acordo com esta perspectiva.

97 Ou seja, estes entes deste primeiro tipo só são considerados acidentes na perspectiva segundo a qual o ente ao qual pertencem é tomado como um sujeito e a causa formal deste, a sua noção definitiva, é tomada como uma causa.

98 Ou seja, a sua ausência acarreta uma privação ou falta numa coisa.

99 Leia-se in-formação, ou seja, a introdução de uma forma.

$100 \mathrm{O}$ contrário de privativa.

$101 \mathrm{Ou}$ seja, do sujeito do qual são predicáveis (genus subiectum como sinónimo de genus praedicabile).

$102 \mathrm{Ou}$ determinações relativas (relativae habitudines).
} 
modos tomam a noção da sua entidade da noção formal do sujeito mas com relação a outra coisa e daqui têm o carácter de propriedades do mesmo modo que os anteriores. E porque desta maneira podem ser algo pertencente a um ente, isto é a sua essência, a qual segundo o modo mencionado tomam formalmente de outra coisa que porém determina e faz isto pela noção que desta maneira os determina e faz ser determinações próprias dos entes. Não são a partir de um acto natural.

(11) O que é primeiramente evidente a partir do fim ${ }^{103}$ porque, como se disse, os entes que são a partir de um acto da natureza são o princípio de uma qualquer operação natural. Mas tal não se verifica nestes entes.

(12) Tal é também evidente a partir da natureza da coisa de cuja noção formal eles são tomados. Pois embora uma coisa possa pela sua essência ser o princípio e a causa da remoção de si mesma de determinações extrínsecas, ela não pode actualizar-se a si própria segundo uma qualquer forma naturalmente real a não ser que esta coisa seja distinta nas suas partes, de modo que tenha em si o princípio do seu movimento e seja movida por si mesma, tal como são os seres animados. Mas não falamos aqui de tais determinações que os seres animados adquirem de si próprios; com efeito, todas estas formas, bem como outras formas naturais, dizem respeito a uma qualquer transmutação real.

(13) E igualmente evidente em terceiro lugar a partir da noção e da natureza própria destes entes, pois, como se disse, eles não são de facto senão ou uma privação, que formalmente é um não-ente, ou, se estabelecem algo positivo em relação a outra coisa, então eles são de tal modo que quer essa coisa exista ou não, real ou mentalmente, eles existem ou não existem fora de toda a transmutação natural, o que não é possível nas formas que importam uma qualquer coisa natural.

(14) É pois necessário aceitar o seu princípio e a sua causa no intelecto de modo como que produtivo ${ }^{104}$, no modo como que subjectivo ${ }^{105}$ na substância ou na essência de uma coisa ${ }^{106}$ e de modo como que originário e informativo ${ }^{107}$ na noção de uma coisa ${ }^{108}$. Com efeito, um sujeito ou uma qualquer forma num sujeito não pode ser a causa eficiente de uma coisa de acordo com a natureza a não ser com respeito a um outro sujeito. É uma característica da noção da causa e do causado que, tal como diferem pela noção, assim são distintos pelo sujeito. E porque a natureza não distingue entre a coisa-sujeito e a noção da coisa-sujeito, sendo o princípio desta distinção o intelecto - ou melhor, o intelecto é o que constitui a noção da coisa neste modo, como abaixo se mostrará -, eis porque os entes que são produzidos a partir da noção formal de uma coisa são criados pelo intelecto ${ }^{109}$.

103 Ou seja, da causa final (cf. 1, 13).

$104 \mathrm{Ou}$ seja, eficiente, effective.

105 De sujeito, subiective.

106 A substância ou a essência de uma coisa funcionam como o seu sujeito ou suporte.

107 Originaliter et informative.

108 Noção de uma coisa é a sua origem e a dadora da sua forma.

${ }^{109}$ Eis uma das premissas-chave para a defesa da tese que é o intelecto que produz 
(15) Logo, em primeiro lugar e originariamente o nosso intelecto agente pela sua faculdade universal e maximamente formal, e depois o intelecto possível actualizado ${ }^{110}$ no que diz respeito à apreensão de uma coisa quanto à sua quididade e noção formal, assim, digo, actualizado de acordo com uma determinada forma a partir da quididade de uma coisa produz estes entes e introduz neles a entidade, de modo que esta é a primeira noção formal da sua entidade, visto que são entes segundo o modo mencionado ${ }^{111}$. De acordo com isto um ente natural pertence, pois, graças ao intelecto à quididade deles e pertence à sua definição ${ }^{112}$ e esta é a primeira raiz e a origem de todos os entes que são por um acto do intelecto quanto àquilo que são e os quais são coisas de primeira intenção ${ }^{113}$ e para a qual raiz devemos remeter a entidade de todos esses entes como sendo o primeiro princípio deste tipo de entes que é por uma operação do intelecto.

estes entes que aqui são tratados como propriedades: visto que a natureza não distingue entre a coisa-sujeito e a noção da coisa-sujeito, uma distinção produzida pelo intelecto, ela não pode ser a causa destes entes que têm a sua origem precisamente na noção formal da coisa-sujeito de acordo com a qual as próprias coisas-sujeito se distinguem entre si.

110 Pelo intelecto agente (ver nota seguinte para a explicação desta actualização).

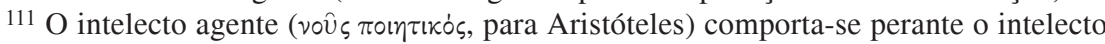
possível (voús $\pi \alpha \theta \eta \tau \iota x o ́ s)$ como o seu princípio activo e emanante (cf. Teodorico Teutónico, De intellectu et intelligibili, III, 36, 1), ou seja, actualiza-o fazendo "reluzir" nele as formas inteligíveis dos objectos (ibid., 36, 3; 35, 2); estes têm que ser entes e o objecto do intelecto é primeiramente e acima de tudo a entidade (cf. ibid., 34, 2). Nesta passagem, Teodorico diz-nos que o intelecto possível, uma vez actualizado pelo intelecto agente, quer dizer, tendo recebido deste as formas que se acordam com a quididade de uma coisa, cria estes entes e dá-lhes assim a entidade, sendo esta assim a primeira noção formal da sua entidade. Eis, pois, o modo como são constituídos ou produzidos pelo intelecto.

$112 \mathrm{Ou}$ seja, um ente natural (uma substância) pertence de facto à quididade de um ente produzido pelo intelecto, pertencendo assim à definição do mesmo.

113 Eis um dos pontos fulcrais do tratado que temos em mãos: para Teodorico, as entidades produzidas pelo intelecto não são meros entes de razão, entia rationis, ou entes de intenção segunda, mas entes de intenção primeira ou coisas realmente existentes. A "revolução" operada por Teodorico repousa exactamente na profunda alteração que ele provoca no sentido das res primae intentionis: se Tomás de Aquino ainda as concebia como meros conceitos, as representações mentais das coisas reais, Teodorico vê-as como coisas com uma existência real e não meramente mental. É significativo que Ockham, por exemplo, comece também ele por ver a intentio prima como a coisa existindo realmente, enquanto a intentio secunda seria aliquid in anima rebus applicabile praedicabile de nominibus rerum (In Sententias I, d. 23D). Note-se, contudo, que esta revolução é relativa, na medida em que a par desta nova concepção das intentiones continua a existir a de Aquino, a qual tinha tido origem mais ou menos directa em Avicena; por exemplo, Pedro Auréolo distingue ainda as intentiones da seguinte forma: “Intenção" é o mesmo que 'conceito', e 'intenção primeira' o mesmo que 'conceito de primeira ordem', o qual o intelecto forma das coisas sem reflectir sobre os seus próprios conceitos. Intenções segundas são conceitos de segunda ordem, que o intelecto constrói por reflexão acerca dos primeiros conceitos" (In Sententias, I, d. 23, art. 2). 
(16) Embora tais entes no modo mencionado recebam uma certa entidade, eles ainda não têm completamente a noção de ente, nem são em algum dos dez géneros senão como propriedades desses mesmos géneros. Têm contudo completamente a noção de ente enquanto basta para constituir um género de categoria se os entes a partir de cuja noção formal estes são tomados forem determinações naturais de algum ente, como abaixo se abordará.

(17) Assim, estes são os entes do primeiro tipo daqueles que de acordo com o terceiro modo proposto no início <do tratado> tomam formalmente a sua entidade de outro ente e de um modo geral pertencem aos entes em si mesmos e são afecções próprias, e encontram-se geralmente em todos os géneros dos entes, tanto de substâncias como de acidentes. E por isto é o primeiro tipo.

(18) O segundo tipo de entes que toma a noção da sua entidade de outro ente ${ }^{114}$ é aquele que pertence a um ente somente em termos de sujeito enquanto sujeito. E assim, entre os nove géneros dos acidentes aos quais este tipo primeira e essencialmente convém encontram-se as quantidades e as qualidades reais que importam uma coisa natural com respeito a uma substância.

(19) Mas uma coisa pode ter a noção de sujeito de dois modos. De um modo enquanto uma coisa está sujeita ${ }^{115}$ a outra nela inerente formalmente de maneira que delas se forma um ente uno como a partir de um sujeito e de uma forma. De outro modo ou por uma outra noção de acordo com o que uma coisa sustenta, ao subsistir, uma qualquer natureza ou determinação a ela aderente.

(20) Digo, pois, que estes entes deste segundo tipo tomam a sua entidade enquanto são entes formalmente de uma outra coisa em termos de sujeito, não no modo daquilo que substá ou de acordo com a noção que substá a uma qualquer forma, substancial ou acidental - com efeito, este modo é o de algo existente em potência e tendo carácter de matéria, pelo que estes entes que segundo este modo só existem noutro não tomariam formalmente dele a noção da sua entidade, mas somente conforme são reduzidos às suas causas, nomeadamente na medida em que uma causa agente produz estes entes num sujeito em relação a um determinado fim $^{116}$-, mas digo que estes entes pertencem a um ente em termos de sujeito no modo daquilo que subsiste em si e essencialmente; de facto, estes entes são criados e existem nele como por um modo de aderência, como determinações naturais dele, embora extrínsecas à sua natureza, determinando-o ao aderir a ele. O que faz com que, visto que um tal ente é um ente no verdadeiro sentido do termo segundo a sua subsistência absoluta, e assim de um modo maximamente formal, os entes que existem nele no modo mencionado tomem a noção da sua entidade dele e sejam formalmente entes porque são determinações de um tal ente. E esta é a essência dos mesmos ${ }^{117}$.

114 Cf. 2,3 acima.

$115 \mathrm{Ou}$ seja, funciona como um sujeito.

$116 \mathrm{O}$ que faria deles somente acidentes pois, como sabemos, segundo Teodorico o fim e o eficiente são causas extrínsecas (cf. acima 1, 10 e abaixo 2, 26).

117 Segundo Teodorico, estes entes são formalmente entes porque são determinações ou disposições (dispositiones) de entes que são entes em termos da subsistência absoluta. Cf. 1, 29-30 acima. 
(21) E porque o termo "determinação"118 ou "aderência" parece implicar alguma acidentalidade, esta acidentalidade deve ser tomada na parte do sujeito a quem ocorre ser assim determinado ${ }^{119}$; mas, por outro lado, ser determinações de um tal sujeito é a essência de tais entes, segundo se considera uma analogia entre eles e a substância em termos de ente e isto é comum a todos os nove géneros, como se mostra no livro IV da Metafísica ${ }^{120}$.

(22) O que propriamente caracteriza estes entes deste segundo tipo é que, quanto àquilo que são, não são produzidos a partir da noção definitiva do sujeito como os anteriores, mas têm a $<$ sua $>$ causa na natureza, pela qual são criados num sujeito em relação a um certo fim.

(23) Só adquirem enquanto entes o carácter de ente a partir de um sujeito no modo indicado. Daqui se considera esta ordem determinada: primeiro o ente que tem uma causa ${ }^{121}$ é constituído no $<$ seu> ser ${ }^{122}$ pelas suas causas; depois considera-se nele a sua entidade formal em termos da quididade e da forma; em seguida, a partir desta noção formal considera-se nele a sua propriedade natural enquanto é um ente.

(24) Embora no respeitante ao primeiro modo ${ }^{123}$ o ente tenha a sua origem de modo essencial, a noção do ente no respeitante ao segundo modo é mais essencial e mais formal e própria; o terceiro dos modos mencionados, ou seja, a propriedade natural dele enquanto é um ente, segue-se do segundo. Quanto ao primeiro modo, estes entes dos quais falamos são criados por um agente num sujeito e têm o carácter de entes naturais, como acima se disse acerca das substâncias; no que diz respeito ao segundo modo considera-se em cada um deles a noção do ente enquanto ente; do que em terceiro lugar é derivada a sua propriedade natural, a qual é a existência ${ }^{124}$ num sujeito, de acordo com Avicena ${ }^{125}$.

$118 \mathrm{Ou}$ disposição, dispositio.

119 Note-se a forma como Teodorico reenvia o carácter de acidentalidade destas determinações - ou seja, entes propriamente ditos! - para o próprio sujeito, na medida em que estas determinações são extrínsecas à natureza do mesmo.

120 Aristóteles, Met. IV, 2, 1003b5-10: "O ser toma-se em múltiplas acepções, mas em cada acepção toda a denominação se faz em relação a um princípio único. Diz-se de umas coisas que são entes porque são substâncias, de outras porque são determinações da substância, de outras porque são um trajecto para a substância ou, pelo contrário, corrupções da substância, ou porque são privações, ou qualidades da substância, ou ainda porque são causas eficientes ou geradoras, seja de uma substância, seja daquilo que é nomeado em relação a uma substância, ou, enfim, porque são negações de qualquer uma das qualidades de uma substância ou negações da própria substância." (Nossa tradução, seguindo de perto J. Tricot: La Métaphysique, Tome I, Paris, Vrin, 1970, p. 177.)

${ }^{121} \mathrm{O}$ ente que é causado, criado a partir de causas.

$122 \mathrm{Ou}$ na sua existência, esse.

123 Os modos de que aqui se trata são aqueles definidos imediatamente acima, em 2, 23.

124 Esse.

${ }^{125}$ Avicena, Logica I, Venetiis, 1508, 9va, 1. 54-60; Averróis, In Aristotelis Metaph. V, comm. 14, ed. Ponzalli, 130. 
(25) Temos ainda que considerar que a noção e o modo destes entes varia em relação ao sujeito conforme varia a noção do sujeito.

(26) Pois se se considerar o sujeito como aquilo que substá, deste modo a partir do sujeito e dos entes é constituído um ente acidental, do qual ente acidental o próprio sujeito é uma parte de acordo com a noção de matéria e do existente em potência, mas aqueles entes que existem nele têm a noção de forma e do existente em acto. E deste modo vê-se que têm tanto o nome como o carácter de acidentes, e são distintos da substância de acordo com o que se diz substância a partir daquilo que substá.

(27) Mas de acordo com o que se diz substância a partir do subsistente, a qual é uma noção de substância mais formal do que a anterior, de acordo com isto são distintos pelas próprias noções e pelo nome de cada um dos géneros sob o nome de, a saber, quantidade, qualidade e de modo semelhante quanto aos outros, porque deste modo considera-se a sua noção própria pela qual são entes e a qual tomam de um ente mais formal que é a substância. E assim quanto a este facto que se considera neles aquilo que são acidentalmente, são mais formais que as substâncias, mas quanto ao facto que se considera neles aquilo que são essencialmente - e isto é a sua essência segundo a noção pela qual são entes -, o sujeito é mais formal do que os mesmos ${ }^{126}$.

(28) Assim, os entes deste segundo tipo são aqueles que importam para as substâncias certas naturezas que são os princípios das suas operações ou dos seus movimentos naturais. $\mathrm{O}$ que pode ocorrer de dois modos, como acima se mencionou.

(29) De um modo tal que sejam princípios de tais movimentos essencial $\boldsymbol{e}$ originariamente. Neste modo são qualidades reais de acordo com as quais as coisas agem ou sofrem, ou são determinadas em termos de alguma perfeição que lhes é apropriada pela natureza. Pelo que o Filósofo no livro V da Metafísica determina a noção de qualidade com relação ao movimento ${ }^{127}$.

(30) De um outro modo, eles são princípios dessas operações ou movimentos, ou até mesmo das perfeições, decerto essencialmente, mas não originariamente. E deste modo são aqueles que são como que indispensáveis para esse fim, como a quantidade e o movimento local, como acima se disse.

(31) Mas põe-se aqui um problema. Visto que a natureza determina determinados movimentos $\boldsymbol{e}$ quantidades em relação a coisas diversas determinadas

126 Parafraseando: o sujeito ou a substância pode ser concebido como aquilo que substá a uma propriedade - caso em que a propriedade é um mero acidente - ou como aquilo que subsiste em si. Neste segundo caso, estamos perante uma noção mais formal de substância ou sujeito; ao subsistir em si, a substância suporta as propriedades que adquirem assim um estatuto distinto: elas constituem os géneros, a saber, a quantidade, a qualidade, etc. Se considerarmos nas propriedades aquilo que são acidentalmente, elas são mais formais que a substância, tomada como aquilo que substá, pois são a forma no sujeito; mas se as considerarmos naquilo que são essencialmente, ou seja, enquanto as nove categorias que se seguem à substância tomada como o subsistente, então esta é mais formal do que elas.

127 Aristóteles, Met. V, 14, 1020b8-25. 
segundo a espécie, mas determina em relação a cada uma delas a sua própria qualidade segundo a existência específica que cada uma delas tem, o segundo modo, no qual se disse que alguns entes tomam formalmente a sua entidade de um outro em termos de sujeito ${ }^{128}$, parece não diferir do primeiro, onde se disse que alguns tomam a sua entidade de um outro de acordo com a noção formal e específica deste ${ }^{129}$.

(32) Mas temos que considerar que é próprio de uma noção que algo tome a sua entidade a partir de outro, pela noção da sua quididade, da noção formal deste como num modo produtivo ${ }^{130}$, mas é próprio de outra noção se ele a tomar a partir de outro de acordo com a natureza especifica deste como num modo de sujeito. $\mathrm{O}$ primeiro convém ao primeiro modo acima mencionado, nomeadamente na medida em que a razão distingue entre o sujeito ou a coisa e a sua noção formal e a partir dela produz estes entes actualizando neles a entidade. O segundo convém a este segundo modo, na medida em que a natureza, que não pode distinguir entre uma coisa e a sua noção formal, determina diferentes naturezas formais de determinadas espécies em relação a coisas diferentes de acordo com as naturezas específicas delas, não contudo a partir dessa natureza específica ou da sua noção formal, mas antes de acordo com ela mesma, como se disse ${ }^{131}$.

(33) A partir destes dois modos ou tipos de entes têm origem os outros dois que se seguem.

(34) O terceiro tipo de entes ${ }^{132}$ é aquele que tem formalmente e em termos de sujeito a sua entidade a partir de um outro, e isto num modo completivo, mas originariamente a partir de um outro ente que é considerado no mesmo sujeito ${ }^{133}$. Estes entes são aqueles que são classificados por si mesmos de acordo com as próprias noções num dos dez géneros de tal modo que não importam nenhuma natureza ou determinação naturalmente real em relação a uma substância quanto àquilo que formal e primeiramente é significado pelo termo, mas têm devido ao seu conceito uma natureza qualquer que tem que se considerar nesse mesmo sujeito.

128 Cf. 2, 3 acima.

129 Cf. 2, 2.

${ }^{130}$ Elicitive, do verbo elicere, obter, fazer sair, produzir.

${ }^{131}$ Como é que um ente toma a sua entidade a partir de outro? Para Teodorico, ele fá-lo de dois modos: ou como num modo produtivo (elicitive), a partir da noção formal do outro ente, ou como num modo de sujeito (subiective), de acordo com a natureza específica deste outro ente. O primeiro convém a 2, 2 na medida em que a razão ou o intelecto distingue entre o sujeito ou a coisa e a sua noção formal (cf. 2, 14 acima) e a partir dela produz estes entes actualizando neles a entidade; o segundo convém a 2, 3 na medida em que a natureza, que não pode distinguir entre uma coisa e a sua noção formal (cf. 2, 14), determina diferentes naturezas formais de determinadas espécies com relação a coisas diferentes de acordo com as suas naturezas específicas segundo si própria. Assim sendo, o facto de a natureza determinar em relação a cada coisa a sua qualidade de acordo com a existência específica de cada uma delas não põe em causa a distinção dos modos distinguidos em 2, 2 e 2,3, pois que neste caso ela fá-lo subiective, no modo de sujeito.

132 Cf. acima $2,4$.

133 Trata-se de relações reais de diferentes acidentes no interior do mesmo sujeito. 
Tais entes são aqueles que pertencem ao género da relação, bem como alguns outros.

(35) Digo "aqueles que pertencem ao género da relação", pois nem todas as relações ${ }^{134}$ pertencem a este modo, nem ao género de categoria que é a relação, por exemplo se algumas são relações só de acordo com a razão e não na realidade. $\mathrm{O}$ que é o caso quer quando os sujeitos de tais relações não são entes senão pela razão, quer se os seus termos ${ }^{135}$ não são distintos senão pela razão, como quando a mesma coisa se relaciona consigo mesma sob a mesma relação. [Est]as relações reais pelas quais alguns entes se relacionam pela sua essência e não por uma qualquer natureza no sujeito não pertencem propriamente a este género de categoria que é a relação; pertencem contudo ao primeiro modo, tal como aí se disse ${ }^{136},{ }^{137}$. Abaixo ver-se-á a razão pela qual são removidas do género categorial.

(36) No livro V da Metafísica ${ }^{138}$, o Filósofo distingue dois modos gerais de todos os entes relativos, a saber, que alguns são relativos essencialmente, outros $<$ são-no> acidentalmente. Os quais dois modos se encontram nos entes relativos de duas maneiras.

(37) De um modo naqueles entes relacionados de modo simples sem que tais entes relativos ou as próprias relações sejam específicos de um género de categoria, como, por exemplo, se alguns entes se relacionam um com o outro pela sua essência em termos de causa e causado, cada um deles se relaciona por si mesmo e não por uma relação que se encontre num género. Se porém alguns entes se relacionarem um com o outro pela sua essência em termos da medida $\boldsymbol{e}$ do medido, cuja relação é considerada entre um primeiro ente e outras substâncias de coisas, então devemos entender que um se relaciona por si mesmo mas o outro o faz acidentalmente, como o Filósofo diz no livro $\mathrm{V}^{139}$.

134 Relativae habitudines.

135 Extrema, os termos da relação.

136 Teodorico refere-se a, por exemplo, a causa e o causado e às potências activa e passiva (cf. 2, 10 acima; cf. 3, 16 abaixo).

137 Parafraseando: as relações são-no quer na realidade quer de acordo com a razão; neste segundo caso, em que ou os sujeitos só são entes pela razão ou os termos da relação só se distinguem pela razão - ou seja, no caso das relações meramente lógicas -, elas não pertencem ao género de categoria que é a relação. Por outro lado, as relações reais, sem consideração ao papel do intelecto no estabelecimento de relações, também não pertencem a este género, nomeadamente na medida em que a sua realidade e entidade se reduzem à realidade e entidade do seu fundamento (cf. 2, 49-53 abaixo). Teodorico diz-nos assim duas coisas importantes para a defesa da sua posição: nem os meros entes de razão, nem os entes naturais tomados completamente independentes do intelecto fazem parte das categorias aristotélicas. Assim, Teodorico altera profundamente o domínio destas, restringindo-o aos entes tal como eles são tomados segundo os poderes criativos ou produtivos do intelecto. Vê-se deste modo que a noção da própria substância enquanto ente simplesmente natural é posta em questão.

138 Aristóteles, Met. V, 15, 1021b3-11.

139 Aristóteles, Met. V, 15, 1021a26-30. A medida é um relativo por essência, pois 
(38) De outro modo se encontra essencial e acidentalmente nos entes que se relacionam por meio de uma relação específica do próprio género; estes encontram-se naquele género de categoria que é a relação e pertencem a este terceiro modo já mencionado. Os entes activos e os passivos não pela sua essência, mas por uma qualquer natureza acidental que se encontre numa substância, de modo semelhante àqueles cuja relação se funda numa proporção numérica, como o igual e o desigual e os entes da sua espécie, são relativos por si quanto a cada um dos termos e classificados num género determinado que é o da relação. $\boldsymbol{O}$ conhecimento e o cognoscível, bem como a sensação e o sensível, embora em relação a um dos termos sejam de facto relativos por si, são-no contudo por acidente no que diz respeito ao outro, e de acordo com isto são específicos de um género quer por si quer por acidente ${ }^{140}$.

(39) Se houver entes dos quais um seja causal ou movente pela sua essência e o outro seja movido de acordo com uma qualquer determinação acidental nele introduzida pelo movente, esse mesmo movente será relativo por si, mas por uma relação não específica de um género; pela relação que se encontra num género e que tem propriamente o carácter de um acidente, ele ${ }^{141}$ não se relaciona senão por acidente, mas o próprio movido relaciona-se por si por este tipo de relação. De acordo com esta distinção e diferença dos relativos vê-se entre os teólogos que umas vezes consideram que Deus tem uma relação por si com as criaturas, outras vezes retiram-lhe contudo este modo de relação, dizendo que ele se relaciona com a criatura só por acidente ou pela razão, sendo os dois modos verdadeiros conforme o diferente carácter mencionado dos relativos; conforme a qual diversidade se vê umas vezes que entre eles as relações pelas quais Deus se relaciona com a criatura são acidentes, mas que outras vezes não o são ${ }^{142}$.

(40) Por esta razão, Anselmo, no capítulo 25 do Monologion, perguntando de que modo se pode conceber Deus como sendo invariável não só num modo substancial, mas também acidental, pois que recebe em si acidentes relativos por meio dos quais se relaciona com a criatura, responde nestes termos: "Mas qual é a inconsistência entre a receptibilidade ${ }^{143}$ dos ditos acidentes e a imutabilidade natural, se da sua recepção não resulta nenhuma mudança numa substância?"

que é esse o seu ser específico (ou seja, ser medida de qualquer coisa); porém, aquilo que é medido é relativo acidentalmente, pois que o seu ser não consiste inteiramente nessa relação. Noutros termos: a medida é-o de $x$, algo, e não medida do mensurável.

140 Cf. Quadro 2 na Introdução para um resumo esquemático de 2,36-38.

$141 \mathrm{O}$ movente.

142 Teodorico mostra que nas relações entre a causa ou o motor (ou movente) e o causado e o movido, ora um ora outro dos termos assume a relação de modo essencial ou por si e de modo acidental; o exemplo que encontra para ilustrar esta ideia é o de Deus que, enquanto causa se relaciona com o causado ora por si mesmo (sob a relação da causalidade propriamente dita) ou acidentalmente (sob outras relações que ele possa estabelecer com os entes criados). No parágrafo seguinte Teodorico recorre à autoridade de Anselmo e Agostinho para desenvolver e defender esta ideia.

143 Ou seja, o carácter de algo que é passível de ser recebido. 
E abaixo: "Pois tal como a natureza suprema nunca sofre qualquer alteração na sua simplicidade devido a acidentes eficientes, do mesmo modo ela não desdenha ser expressa por esses acidentes que de modo nenhum são inconsistentes com a suprema imutabilidade". E opina do seguinte modo acerca do carácter diferente do acidente neste género: "Assim como aqueles acidentes que pela sua presença ou ausência causam uma alteração são avaliados pelo efeito que têm de facto sobre uma coisa, assim devemos considerar que aqueles que não possuem o mesmo efeito são ditos acidentes impropriamente." E conclui no mesmo capítulo, os acidentes relativos causam uma mutação com respeito a um sujeito num modo relativo ${ }^{144}$, nomeadamente porque eles não são enquanto relações, mas por uma razão natural que é o fundamento da relação, tal como os graus de calor, as cores e assim por diante, como diz no mesmo capítulo. Agostinho defende a mesma opinião acerca das relações no último capítulo do livro $\mathrm{V}$ de $A$ Trindade ${ }^{145}$.

(41) Contudo, há quem queira chamar relativos pela razão aos relativos por acidente dos quais falámos ${ }^{146}$, mas o significado não deve ser feito nas palavras a menos que corresponda à verdade das coisas. Há um aspecto que temos de considerar acerca desta questão: que a noção destes modos, a saber, em si e acidental, é tal que ambos pertencem à mesma classe, de modo que se um deles for em realidade ${ }^{147}$, o outro será em realidade, o que é evidente pela natureza e pela noção da origem daquilo que é por acidente a partir daquilo que é em si. De facto, a noção daquilo que é por acidente consiste numa certa analogia com aquilo que é em si. Pelo que aquilo que é em si cai na sua própria definição ${ }^{148}$; o que não acontece naqueles entes que diferem pelas diferenças que são em realidade e pela razão. No entanto, pode-se dizer daquilo que é por acidente que é pela razão no sentido alargado do termo, como os nossos veneráveis doutores de teologia ${ }^{149}$ frequentemente o fazem neste modo.

(42) Voltemos, porém, à questão geral acerca dos entes deste terceiro tipo. Visto que a noção de tais entes enquanto entes é tomada simultaneamente a partir do sujeito e de outra coisa que se considera nesse mesmo sujeito, tal como acima se disse, é por isso que os mesmos pertencem ao tipo dos entes que são formas tornando-se intrinsecamente presentes ${ }^{150}$ : embora alguns deles necessitem de algo extrínseco sob o aspecto do termo ${ }^{151}$, não necessitam

144 Oposto de modo absoluto ou simpliciter.

145 Agostinho de Hipona, De Trin. V, 16, n. 17; PL 42/922-924.

146 Tomás de Aquino, In I Sent. d. XXX, q. 1, a. 1. co.; Summa theol. I, q. 13, a. 7 co.

147 Ou seja, real.

148 Teodorico argumenta que não é pelo facto de um ente se relacionar com outro de modo acidental que ele é um ente relativo só pela razão: se aquilo com o qual um ente se relaciona por acidente for na realidade, ele sê-lo-á também, nomeadamente na medida em que aquilo que é em si mesmo pertence à definição daquilo que é o seu acidente.

149 Teodorico refere-se muito provavelmente a Tomás de Aquino; ver notas imediatamente acima.

${ }^{150}$ Formae intrinsecus advenientes.

151 Ou seja, tomados como um termo. 
dele para dele tomarem a noção da sua entidade, como é evidente no caso das relações.

(43) Estes entes originam-se a partir dos dois tipos anteriores neste <terceiro $>$ modo ${ }^{152}$.

(44) Em primeiro lugar, estes entes tomam a sua entidade de um outro segundo a noção formal deste; e de acordo com isto têm o modo das propriedades de algo natural e pertencem assim ao primeiro tipo acima ${ }^{153}$.

(45) Recebem contudo a natureza e o modo de um ente classificável num género pelo facto que a coisa de acordo com cuja noção formal e definitiva são tomados é uma determinação natural de uma substância; o que pertence ao segundo tipo já mencionado ${ }^{154}$.

(46) Daqui agora em terceiro lugar estes entes são em relação à substância como determinações e modos acidentais dela, e são entes porque pertencem a um ente, a saber, a uma substância na maneira de um sujeito no qual existem, não enquanto produzidos a partir da sua noção formal, mas, como se disse, acidentalmente mediante essa natureza e com essa natureza a partir da qual em primeiro lugar e originariamente tomaram a sua entidade nesse mesmo sujeito existente, como se disse, por exemplo a quantidade contínua, pois é uma determinação de uma substância e um acidente real de facto de acordo com a natureza.

(47) De acordo com isto, o uno, que é tomado em termos da quantidade contínua em relação a uma substância corpórea, adquire a natureza de um acidente classificável num género e é o princípio do número que segue a divisão do contínuo, segundo o Filósofo ${ }^{155}$, e é um acidente nas coisas corpóreas. Contudo, o uno, relacionado imediatamente com uma substância tendo sido circunscritos ou removidos todos os acidentes da substância, não tem a natureza nem o modo de um acidente classificável num género, mas tão-somente de uma propriedade natural daquilo que produz um tal ente. E aquilo que se disse do uno aplica-se de igual modo aos outros entes que pertencem a este tipo.

(48) Mas porque estes entes, assim como todos os outros que existem em substâncias, têm o carácter de um ente segundo uma analogia com a substância, temos que considerar nestes entes, de acordo com o que se disse acima, que a sua entidade, pela qual são constituídos num dos dez géneros, consiste numa analogia dupla. Em primeiro lugar, eles adquirem o carácter de entes de certo modo de acordo com a noção formal de um outro ente natural, como se disse. No entanto, este ente natural é um ente mais remoto ${ }^{156}$ porque é um acidente ou uma determinação natural de um ente real que é uma substância. E assim a noção desta analogia completa formalmente a noção da primeira analogia ao

152 Teodorico refere-se aos dois tipos tratados imediatamente acima pertencentes ao terceiro modo de principiar um ente; quer isto dizer que a relação vai ser "reduzida" aos dois tipos de entes anunciados em 2, 2 e 2, 3.

153 Cf. 2, 2 acima.

154 Cf. 2, 3.

155 Aristóteles, Met. V, 15, 1021a12-13; ibid. V, 6, 1016b17-18; ibid. X, 1, 1052b20-24.

156 Tem um estatuto ontológico inferior. 
constituir estes entes, de modo que possam significar uma coisa de intenção primeira classificável num género.

(49) E isto é aquilo que alguns ${ }^{157}$ querem dizer, que a realidade de tais entes não é senão a realidade do seu fundamento.

(50) Se entendem pelo termo "coisa" ou "realidade" uma qualquer natureza ou determinação natural, então é acordado que uma tal realidade só se encontra no fundamento de tais entes. Embora formal e primeiramente não a signifiquem pelo termo, importam-na do seu conceito com relação a uma substância, e é quase o mesmo que, se eu entendesse pelo termo "ente" só aquilo que é em si e subsiste de modo absoluto, diria que toda a entidade de um qualquer acidente não é senão a entidade do fundamento, o qual é a substância.

(51) Se, contudo, entendem pelo termo "coisa" ou "realidade" o que quer que seja que de algum modo é de acordo com a noção de um qualquer acto formal pela qual ela é uma coisa de intenção primeira, então a opinião deles é correcta quanto ao facto que a noção formal destes entes e a do fundamento é a mesma: de facto, a noção definitiva exprimindo a essência ${ }^{158}$ dessa coisa que é o fundamento é a mesma que exprime a causa ${ }^{159}$ destes entes. E esta é a primeira noção de uma certa entidade neles pela noção neles actualizando esta entidade de acordo com a dita noção. Tal como estes entes em primeiro lugar e originariamente tomam uma certa entidade a partir do seu fundamento, assim a partir do mesmo elas tomam tanto a natureza de um género categorial como a natureza de um acidente com relação a uma substância, nomeadamente de maneira que tenham o modo e a natureza de acidentes reais de uma substância.

(52) Mas se quisermos reduzir estes entes às suas causas, então, embora pela noção do fundamento tenham uma causa na natureza, pela noção daquilo que formal e primeiramente é significado pelo termo e no qual consiste a noção do seu próprio género, são a partir de uma operação do intelecto ${ }^{160}$. De facto, a natureza não produz nem realiza nada a partir da noção de uma coisa, tal como não distingue entre a coisa e a noção da coisa, mas esta é a obra própria do intelecto, como abaixo se dirá.

(53) Se removermos destes entes o acto da razão, então não serão de modo nenhum entes quanto àquilo que é significado pelo termo, restando somente a realidade e a entidade do fundamento. E assim no terceiro modo a opinião deles pode ser corroborada, mas menos propriamente, porque nesta perspectiva estes entes não são classificados num género próprio senão talvez somente pela designação, pela qual o metafísico não distingue estes géneros de coisas.

(54) Estes são pois os entes do terceiro tipo acerca dos quais é de certo modo evidente porque razão são entes enquanto entes e a que causas têm que ser reduzidos.

${ }^{157}$ Henrique de Gand, Quodl. V, 2, ad arg., Parisiis 1518, 155rN; ibid. IX 3 corp., 349rT-V; ibid. IX, 3 ad arg. 1, 35lrE.

158 Quid est.

159 Propter quid.

160 Note-se que já em 1, 19-20 acima Teodorico havia determinado o carácter não-natural e puramente intelectual das (de algumas?) relações, recusando porém vê-las como meras coisas de razão. 
(55) O quarto tipo de entes ${ }^{161}$, o qual tal como o modo anterior depende formalmente de um outro por essência, é aquele no qual é um ente porque pertence a um ente em termos de sujeito, mas de acordo com outra coisa qualquer que se considera nesse mesmo sujeito, e originalmente a partir da noção de um outro ente que é diferente do sujeito. E este é em termos da origem o primeiro na noção formal deste ente.

(56) E por causa disto se diz de cada um destes entes que tem uma origem extrínseca. Por exemplo, o próprio lugar, que é uma coisa de um determinado género, um de dez, ele próprio, digo, é um ente porque pertence a um ente em termos de sujeito - o qual é uma substância - naquele modo como se disse acima acerca de outros entes. Ele existe numa substância pelas suas ${ }^{162}$ dimensões, as quais a natureza considera antes da substância, e existe assim num sujeito de acordo com qualquer outra coisa que se considera nesse mesmo sujeito. Mas antes de tudo ele existe num sujeito em termos do lugar continente ${ }^{163}$, o qual é diferente do sujeito, pelo que em Acerca dos Seis Princípios ${ }^{164}$ se diz que o lugar é a circunscrição de um corpo procedente da circunscrição do lugar. $\mathrm{E}$ o mesmo se aplica aos outros entes que pertencem ao mesmo modo.

(57) A noção formal destes entes tem a sua origem assim a partir do exterior, mas alcança a formalidade da sua natureza no sujeito em termos da qual eles inerem; a noção de ente realiza-se neles pela sua relação final com a substância na qual existem.

(58) Estes entes são de um modo geral no número dos seis géneros dos quais dizemos que são formas com uma origem extrínseca. Estes entes devem reduzir-se ao mesmo modo e às mesmas causas em género que os anteriores pertencentes ao terceiro tipo.

(59) Mas poder-se-á agora perguntar porque razão, de acordo com os entes que são tomados a partir da noção formal e definitiva de uma substância, não se constitui um género de categoria distinto do género da substância em termos da própria noção, como vemos que tal acontece no caso de outros géneros, por exemplo o igual e o desigual em termos da quantidade, o semelhante e o dissemelhante, que são certas relações, em termos da qualidade, em termos do local ${ }^{165}$ o próprio lugar, e de igual modo no caso de muitos outros.

(60) Mas temos que considerar que os modos dos entes que são tomados da noção da substância e daqueles que são tomados da noção de um outro género são diferentes. De facto, os entes que são a partir de uma substância, têm sempre o mesmo respeito e relação com a substância, nomeadamente em termos de acidentes próprios e paixões essenciais da substância. Na medida em que são tomados a partir de uma substância em termos da sua quididade, não podem respeitar um outro ente diferente da substância pela razão que a substância é um

161 Cf. acima 2, 5.

162 Do sujeito.

163 Que contém.

${ }^{164}$ Liber sex princ. V, 48, ed. Minio Paluello - Dod, 45.

$165 \mathrm{Ou}$ espaço; trata-se aqui do locus a partir do qual se considera a categoria do lugar, ubi (à letra: "onde"). 
ente em si em termos de subsistência absoluta, pelo que pertencem ao mesmo género em termos de propriedades da substância.

(61) Contudo, as coisas dos outros géneros podem considerar-se de modo duplo. Num modo em termos da sua natureza em si e absolutamente, sem a noção do sujeito, e as que deste modo são pensadas a partir da noção dos próprios géneros são consideradas como modos próprios de tais naturezas e têm o carácter de propriedades. E deste modo não são excluídos da noção do próprio género a partir de cuja noção são tomados.

(62) Num outro modo consideram-se as coisas dos outros géneros com relação ao sujeito enquanto são certas determinações de uma substância. E deste modo algumas podem a partir da noção deles ser tomadas em relação a uma substância como modos e determinações da substância. E assim cada um destes entes tem uma certa noção própria de um género determinado enquanto é tomado assim a partir da noção de uma qualquer natureza, não como sendo um modo ou uma propriedade qualquer dessa mesma natureza, mas como sendo um certo modo e determinação da substância de acordo com essa própria natureza. Uma tal propriedade encontra-se entre a natureza e a noção do género do próprio sujeito; mas aquilo que é pensado em termos de uma natureza qualquer é pensado em relação a outra coisa como uma forma tendo a noção própria de um determinado género relativo à substância, embora no seu conceito importe em relação à substância a natureza deste género, a partir de cuja noção é tomado. E estes são aqueles que pertencem ao terceiro e quarto tipo de entes, como se disse. 